\title{
Wind-driven interannual variability of sea ice algal production in the western Arctic Chukchi Borderland
}

\author{
E. Watanabe ${ }^{1}$, J. Onodera ${ }^{1}$, N. Harada ${ }^{1}$, M. N. Aita ${ }^{1}$, A. Ishida ${ }^{2}$, and M. J. Kishi ${ }^{3}$ \\ ${ }^{1}$ Japan Agency for Marine-Earth Science and Technology, 2-15 Natsushima, Yokosuka, Kanagawa, 237-0061, Japan \\ ${ }^{2}$ Department of Social and Environmental Studies, Tokoha University, Fuji, Shizuoka, Japan \\ ${ }^{3}$ Faculty of Fisheries Sciences, Hokkaido University, Hakodate, Hokkaido, Japan \\ Correspondence to: E. Watanabe (ejnabe@jamstec.go.jp)
}

Received: 23 April 2015 - Published in Biogeosciences Discuss.: 22 May 2015

Revised: 5 October 2015 - Accepted: 14 October 2015 - Published: 28 October 2015

\begin{abstract}
Seasonal and interannual variability in the biogenic particle sinking flux was recorded using multi-year bottom-tethered sediment trap mooring systems in the Northwind Abyssal Plain (Station NAP: $75^{\circ} \mathrm{N}, 162^{\circ} \mathrm{W}, 1975 \mathrm{~m}$ water depth) of the western Arctic Chukchi Borderland. Trapped particle flux at a median depth of $184 \mathrm{~m}$ had an obvious peak and dominance of sea ice-related diatom assemblages in August 2011. The observed particle flux was considerably suppressed throughout summer 2012. In the present study, the response of ice algal production and biomass to wind-driven changes in the physical environment was addressed using a pan-Arctic sea ice-ocean modeling approach. A sea ice ecosystem with ice algae was newly incorporated into the lower-trophic marine ecosystem model, which was previously coupled with a high-resolution (i.e., $5 \mathrm{~km}$ horizontal grid size) sea ice-ocean general circulation model. Seasonal model experiments covering 2-year mooring periods indicated that primary productivity of ice algae around the Chukchi Borderland depended on basin-scale wind patterns via various processes. Easterly winds in the southern part of a distinct Beaufort High supplied nutrientrich water for euphotic zones of the NAP region via both surface Ekman transport of Chukchi shelf water and vertical turbulent mixing with underlying nutricline water in 2011. In contrast, northwesterly winds flowing in the northern part of an extended Siberian High transported oligotrophic water within the Beaufort Gyre circulation toward the NAP region in 2012. The modeled ice algal biomass during summer reflected the differences in nutrient distribution. The modeled sinking flux of particulate organic nitrogen (PON) was comparable with the time series obtained from sediment trap data
\end{abstract}

in summer 2011. In contrast, lateral advection of ice algal patches of shelf origin during a great cyclone event may have caused a modeled PON flux bias in 2012. Sensitivity experiments revealed several uncertainties of model configurations of ice algal productivity, particle sinking speed, and grazing activities. Extending the year-long measurements is expected to help illustrate the more general features of ice-related biological processes in the Arctic Ocean.

\section{Introduction}

The response of biogeochemical cycles to the decline in Arctic sea ice has become an important topic for a variety of communities. Improved light conditions during summer have enhanced phytoplankton photosynthesis activity in the Eurasian pelagic area of the Arctic Ocean (Wassmann, 2011). A widespread massive deposition of ice algal biomass was detected on the deep seafloor of the eastern Arctic basin (Boetius et al., 2013). On the other hand, the under-ice export of particulate organic carbon (POC) was limited by insufficient nutrient supply in the stratified central Arctic (Lalande et al., 2014). In the Beaufort Gyre region of the western Arctic, freshwater accumulation suppressed primary production during the 2000s (McLaughlin et al., 2010; Nishino et al., 2011). It is necessary to fill in the observational gaps to understand spatial and temporal variability in the biological processes of the Arctic Ocean.

Sediment trap measurements are useful to capture yearlong biological activity signals. The locations of bottomtethered traps have been confined to the north of the 
Laptev Sea (Fahl and Nöthig, 2007), Mackenzie shelf (Forest et al., 2007), and the deep Canada Basin (Honjo et al., 2010; Hwang et al., 2015). In our field campaign, yearround bottom-tethered moorings, including sediment trap instruments, have been deployed in the Northwind Abyssal Plain (NAP) of the Chukchi Borderland since October 2010 (Fig. 1). Early-winter maxima of sinking particle flux with fresh organic material have been captured annually at Station NAP $\left(75^{\circ} \mathrm{N}, 162^{\circ} \mathrm{W}, 1975 \mathrm{~m}\right.$ water depth) (Watanabe et al., 2014; Onodera et al., 2015). The substantial quantities of lithogenic minerals in the trapped particles suggest shelf-origin water transport toward the NAP region. Seasonal experiments using an eddy-resolving ( $5 \mathrm{~km}$ grid size) pan-Arctic sea ice-ocean model indicated the effective role of Beaufort shelf-break eddies in the transport of Chukchi shelf water with high biological productivity and in the consequent early-winter peaks of sinking biogenic flux at Station NAP (Watanabe et al., 2014). It should be noted that biological production continued inside these eddies moving in the southern Canada Basin.

Another finding obtained at Station NAP was remarkable interannual variability in summer particle flux (Onodera et al., 2015; Ikenoue et al. 2015; Matsuno et al., 2015). Trapped particle flux peaked sharply in August 2011 but was suppressed considerably during summer 2012. The diatom assemblage compositions suggest that year-to-year changes in the distribution of shelf-origin water and relatively oligotrophic water originating from the interior of the Canada Basin controls the particle flux around the Chukchi Borderland (Onodera et al., 2015). This situation was supported by ocean current fields simulated in a medium-resolution $(25 \mathrm{~km}$ grid size) framework by the pan-Arctic physical oceanographic model (Onodera et al., 2015). However, reliable in situ biological productivity and water mass transport data above the shallow trap depth (approximately 180-260 m) was not available at Station NAP during the mooring periods (October 2010-September 2012). In particular, chlorophyll, nutrient concentration, and ocean velocity data from winter to early summer were insufficient. Further detailed investigation of the background mechanisms associated with summer biogenic flux would be highly valuable and possible using a coupled physical and marine ecosystem model. Whereas the main content of observed diatom valves was the sea ice-related species (e.g., Fossula arctica, Onodera et al., 2015), the sea ice ecosystem was not included in our previous model experiment (Watanabe et al., 2014). The lack of ice algae was a plausible factor for the summer delay of the simulated biogenic flux peak behind the trap data. These issues raised our motivation to incorporate ice-related biogeochemical processes in the model.

Ice algae models have a long history of development. Pioneering work was conducted on the Antarctic fast ice ecosystem (Arrigo et al., 1993). For the Arctic Ocean, onedimensional ice algae models were applied to landfast ice in Resolute Passage of the Canadian Archipelago (Lavoie et al., 2005; Pogson et al., 2011) and offshore Barrow (Jin et al., 2006). The modeled region has been extended in recent years to include the entire Arctic Ocean (Dupont, 2012) and global domain (Deal et al., 2011; Jin et al., 2012). The analysis period covered seasonal transition (Lavoie, 2005; Deal et al., 2011) to decadal variability (Jin et al., 2012; Dupont, 2012) and future projections (Lavoie et al., 2010). Most models assume that ice algal activity occurs primarily in the skeletal layer of the sea ice bottom (i.e., ice-water interface), where the layer thickness is fixed at $2 \mathrm{~cm}$ (Lavoie et al., 2005), $3 \mathrm{~cm}$ (Jin et al., 2012), and $5 \mathrm{~cm}$ (Dupont, 2012). The ice algal biomass sometimes reaches values 3 orders of magnitude larger at the ice-water interface than that in the upper part of the sea ice column (e.g., Jin et al., 2006). Ocean surface water is a major nutrient supplier for ice algae in the skeletal layer. Tidal mixing controls nutrient exchange rates at the ice-water interface in the narrow shallow straits of the Canadian Archipelago (Lavoie et al., 2005). In a general viewpoint, it is reasonable that nutrient flux is calculated as a function of the sea ice freezing/melting rate (Arrigo et al., 1993; Jin et al., 2006). However, Dupont (2012) did not calculate nutrient import due to sea ice freezing, following an observational view where nutrients trapped inside the sea ice column have minor contributions to an ice algal bloom (Cota et al., 1991; Cota and Smith, 1991). As grazing pressure on ice algae is considered weak in the sea ice column, most previous models excluded zooplankton biology in the skeletal layer (Jin et al., 2006; Dupont, 2012) or prescribed a small grazing rate to potential grazers (e.g., amphipods) (Lavoie, 2005). The habitat of ice algae in the skeletal layer disappears gradually due to melting sea ice. The assemblages released from the sea ice bottom partially act as phytoplankton and become a food source for pelagic grazers in the water column (Michel et al., 1993, 1996). Thus, complex ice algal processes have been proposed and numerically formulated in various ways.

In the present study, seasonal and interannual variability of ice algal production and biomass in the Chukchi Borderland were addressed using a pan-Arctic sea ice-ocean modeling approach (Fig. 1). We focused particularly on the relationships between ice-related biogeochemical processes and wind-driven dynamics, such as shelf-basin exchanges, local upwelling/downwelling, and vertical turbulent mixing. To represent the summer biogenic particle flux captured by sediment trap measurements, the simple sea ice ecosystem was newly incorporated into a lower-trophic marine ecosystem model. Our model coupled with a sophisticated highresolution physical component is a powerful tool for the above-mentioned subjects because of following issues. The Chukchi Borderland is composed of complex topography such as long ridges, deep-sea plateaus, and steep shelf breaks. The sinking biogenic flux available for comparison was obtained from the single-point mooring measurements in this area. The source regions of surface water are distributed over the Chukchi Sea, the East Siberian Sea, and the Canada 

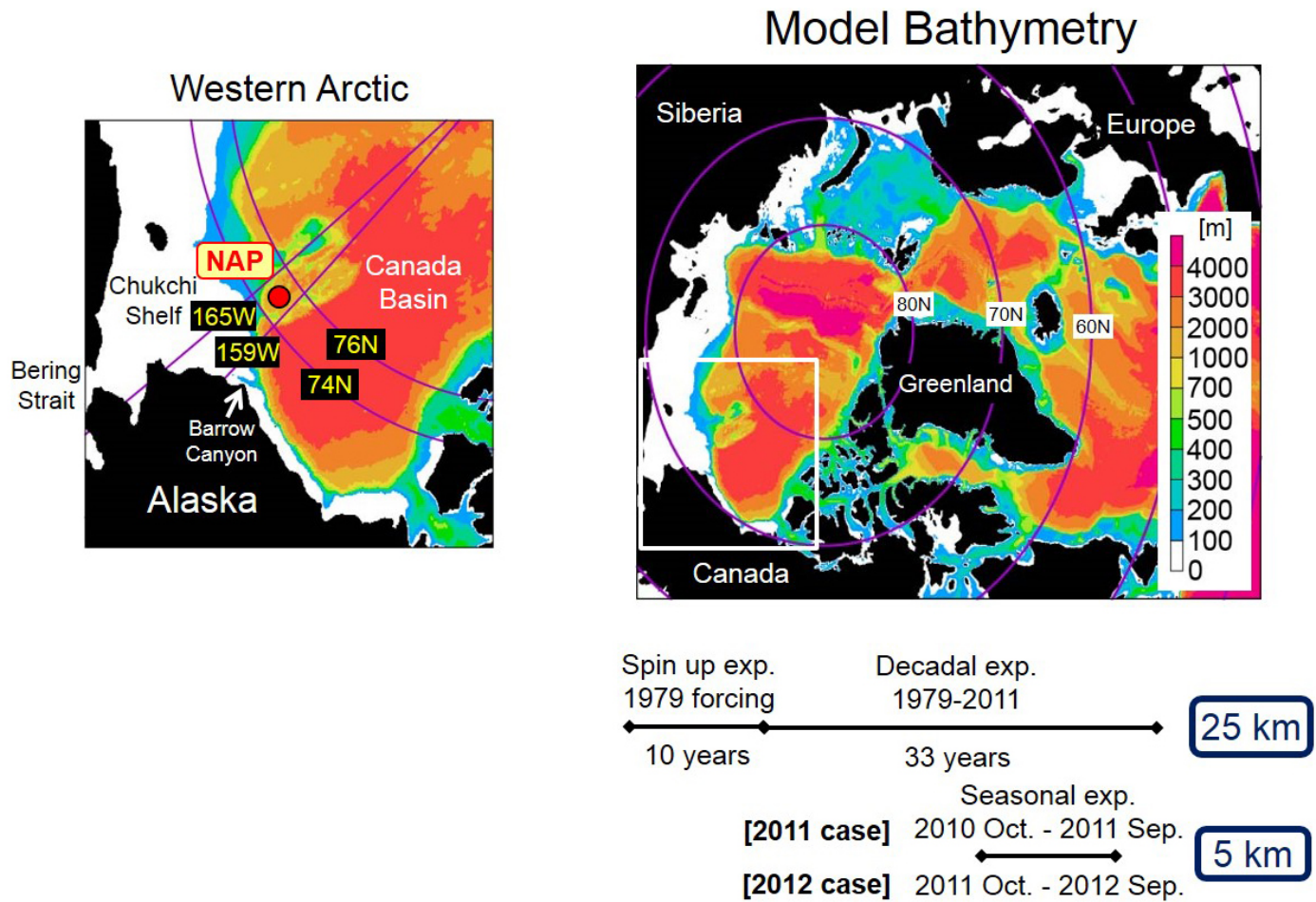

Figure 1. Bathymetry of the pan-Arctic sea ice-ocean model COCO. Location of Station NAP is indicated by a red dot in the left enlarged view. The NAP region defined in the present study is enclosed by $74-76^{\circ} \mathrm{N}$ and $159-165^{\circ} \mathrm{W}$. The model integration period covers 33 years from 1979 to 2011 only for the physical oceanographic part using the $25 \mathrm{~km}$ resolution version, and the obtained fields are given as initial condition for 1 year experiment from October 2010 (2011) to September 2011 (2012) in the 2011 (2012) case using the $5 \mathrm{~km}$ resolution version with marine ecosystem components.

Basin. The water mass transports are closely related to shelfbasin boundary currents and baroclinic eddies. These complex topography and mesoscale hydrographic features have been unresolved by previous basin-scale ice algae models, which horizontal resolution was much coarser than the typical internal Rossby radius of deformation (ca. $10 \mathrm{~km}$ ) in the polar region (Zhao et al., 2014). The linkages between wind patterns, light and nutrient preconditioning of ice algal bloom, and particle sinking are also unique viewpoints in the present work. Modeling configurations and sediment trap analyses are described in Sect. 2. Seasonal transitions of the modeled ice-ocean field, particularly those around the NAP region, are traced in Sect. 3. Relationships between the interannual variability in biogeochemical properties and wind patterns are examined in Sect. 4. Uncertainties of the modeled processes are discussed in Sect. 5, based on sensitivity experiments. The obtained findings are summarized in Sect. 6.

\section{Model configuration and experimental design}

\subsection{Physical oceanographic model}

The physical part of the coupled sea ice-ocean model is the "Center for Climate System Research Ocean Component Model (COCO)" version 4.9 (Hasumi, 2006). The sea ice component includes a multi-thickness-category configuration based on that of Bitz et al. (2001) with a one-layer thermodynamic formulation (Bitz and Lipscomb, 1999), the linear-remapping method for category transfer (Lipscomb, 2001), and the elastic-viscous-plastic rheology (Hunke and Dukowicz, 1997). In addition to the open water category, the lower limit of sea ice thickness in each category is set to 10 , $30,60,100,250$, and $500 \mathrm{~cm}$, respectively (i.e., 7 categories). The ocean component is a free-surface general circulation model formulated using the advection scheme of Leonard et al. (1994) and the turbulence closure mixed-layer scheme of Noh and Kim (1999).

\subsection{Marine ecosystem model}

The COCO model was coupled with a lower-trophic marine ecosystem model, "North Pacific Ecosystem Model for Understanding Regional Oceanography (NEMURO)". The de- 
tailed configuration of the original NEMURO model, which represented pelagic plankton species (i.e., diatom, flagellate, and copepod), was described in Kishi et al. (2007). To address seasonality and interannual variability in ice algal production and biomass, a sea ice ecosystem was incorporated in the present work, (Fig. 2 and Table 1). In the developed model (called "Arctic NEMURO", hereafter), the habitat of ice algae is confined to the $2 \mathrm{~cm}$ skeletal layer. The biogeochemical variables in the sea ice component comprise ice algae (IA), ice-related fauna (IF), nitrate $\left(\mathrm{NO}_{3}\right)$, ammonium $\left(\mathrm{NH}_{4}\right)$, silicate (SIL), dissolved organic nitrogen (DON), particulate organic nitrogen (PON), and opal (OPL). Each model grid has a single value per variable independent of the ice thickness category. As the sea ice bottom temperature is always kept at the freezing point of underlying seawater, a relationship of $Q_{10}=2$ adopted in the present model did not have substantial impacts on biogeochemical cycles in the sea ice column. The growth rate of ice algae (GR) is calculated depending on light condition $(L)$ and nutrient uptake $\left(N_{\text {up }}\right)$ terms:

$\mathrm{GR}=\mathrm{GR}_{\max } \times L \times N_{\text {up }}$,

where the maximum growth rate $\mathrm{GR}_{\max }$ is fixed at a constant value of $0.8 \mathrm{~d}^{-1}$.

The light condition term followed the original NEMURO formulation:

$$
\begin{aligned}
& L=I / I_{\mathrm{opti}} \times \exp \left(1-I / I_{\mathrm{opti}}\right), \\
& I=\operatorname{PAR}_{\mathrm{frac}} \times \mathrm{SW}^{\downarrow} \times\left(1-\alpha_{\mathrm{sfc}}\right) \\
& \times \exp \left(-k_{\text {snow }} H_{\text {snow }}-k_{\text {ice }} H_{\text {ice }}\right),
\end{aligned}
$$

where $I$ is photosynthetically active radiation (PAR) in the skeletal layer. The conversion coefficient from shortwave radiation to PAR ( $\mathrm{PAR}_{\text {frac }}$ ) is 0.43 following the previous models (Zhang et al., 2010; Dupont, 2012) so that $43 \%$ of shortwave flux is available for photosynthesis activity. Light transmission through the snow and sea ice columns is given by downward shortwave radiation from atmosphere $\left(\mathrm{SW}^{\downarrow}\right)$, snow/ice surface albedo $\left(\alpha_{\text {sfc }}\right)$, column thickness $\left(H_{\text {snow }}\right.$, $\left.H_{\text {ice }}\right)$, and empirical extinction rates $\left(k_{\text {snow }}, k_{\text {ice }}\right)$. The surface albedo $\left(\alpha_{\mathrm{sfc}}\right)$ changes from 0.8 to 0.6 depending on snow/ice type and surface temperature during summer. The light extinction rate $\left(k_{\text {snow }}, k_{\text {ice }}\right)$ is set to $0.12 \mathrm{~cm}^{-1}$ for snow and $0.045 \mathrm{~cm}^{-1}$ for sea ice based on Aota and Ishikawa (1982). According to this constant rate, for example, the light intensity in the skeletal layer corresponds to approximately $10 \%$ (1\%) of that absorbed into the surface of sea ice with its thickness of $50 \mathrm{~cm}(100 \mathrm{~cm})$ (Fig. 3a). The light transmission is calculated in each thickness category (see the category arrangement in Sect. 2.1), and the under-ice average intensity is then obtained in each model grid. A self-shading effect of ice algae is neglected. For weak-light adaptation of ice algae, the optimal light intensity $\left(I_{\text {opti }}\right)$ is set to $10 \mathrm{~W} \mathrm{~m}^{-2}$ (cf.
$104 \mathrm{~W} \mathrm{~m}^{-2}$ for pelagic phytoplankton; Kishi et al., 2007). A PAR of 5 and $20 \mathrm{~W} \mathrm{~m}^{-2}$ results in a light condition term of 0.82 and 0.73 , respectively (Fig. 3 b).

The vertical exchange of biogeochemical variables between the skeletal layer and the ocean surface layer (suffixed as SKL and OCN, respectively, hereafter) is formulated in a different manner for sea ice freezing and melting periods. During the freezing period, ocean-to-ice fluxes $F_{\mathrm{OI}}$ are proportional to sea ice freezing rate IFR:

$F_{\mathrm{OI}}=\mathrm{CF}_{\mathrm{OI}} \times\left(\mathrm{NO}_{3}, \mathrm{NH}_{4}, \mathrm{SIL}, \mathrm{DON}\right)_{\mathrm{OCN}} \times \mathrm{IFR}$.

The proportional coefficient $\mathrm{CF}_{\mathrm{OI}}$ is set to 0.3 , since firstyear ice salinity is able to reach approximately $30 \%$ of ocean salinity. In addition, all of the imported nutrients are accumulated only in the skeletal layer. The actual ice algae respond to nutrients concentrated in brine pockets and channels. However, the incorporation of such detailed structures in sea ice interiors is generally difficult for three-dimensional climate models. Here, we regard the skeletal layer as the reservoir of total imported nutrients under an idealized assumption. There is no import of particles such as pelagic planktons, PON, and OPL. During the melting period, iceto-ocean fluxes $F_{\mathrm{IO}}$ are proportional to the sea ice melting rate IMR:

$F_{\mathrm{IO}}=\left(\mathrm{IA}, \mathrm{IF}, \mathrm{NO}_{3}, \mathrm{NH}_{4}, \mathrm{SIL}, \mathrm{DON}, \mathrm{PON}, \mathrm{OPL}\right)_{\mathrm{SKL}} \times \mathrm{IMR}$.

According to this formulation, the concentration of all biogeochemical variables in the sea ice component decreases to zero when sea ice entirely disappears due to the melting process in each model grid. Although sea ice melts from its surface, bottom, and flank, respectively, it is difficult to separate these melting processes in terms of particle export. In general, ice surface meltwater sinks through internal brine channels and flushes out a part of materials in the skeletal layer (Vancoppenolle et al., 2010). Besides, ice algae have an ability to maintain their position under a slow melting rate, and the habitat is not immediately lost even after ice bottom melting. The methods adopted in the present work idealize ice-ocean exchange of biogeochemical variables within reasonable scopes.

The nutrient source of ice algal growth can be divided between the sea ice column and underlying seawater. The present study assumes that ice algae utilize both ice/ocean nutrients depending on their biomass:

$N_{\text {up }}=\mathrm{RN}_{\text {upSKL }} \times N_{\text {upSKL }}+\left(1-\mathrm{RN}_{\text {upSKL }}\right) \times N_{\text {upOCN }}$, $\mathrm{RN}_{\text {upSKL }}=0.5 \times\left\{\cos \left(\pi \times \mathrm{IA} / \mathrm{KN}_{\text {upSKL }}\right)+1\right\}$,

for $\mathrm{IA} \leq \mathrm{KN}_{\mathrm{upSKL}}$,

where $\mathrm{RN}_{\text {upSKL }}$ is the ice algal uptake ratio of nutrient in the skeletal layer, and $\mathrm{KN}_{\text {upSKL }}$ is a threshold value (Fig. 3c). When ice algal biomass IA exceeds $\mathrm{KN}_{\text {upSKL}}$, only seawater nutrients are utilized for the growth. The value of $\mathrm{KN}_{\mathrm{upSKL}}$ is 


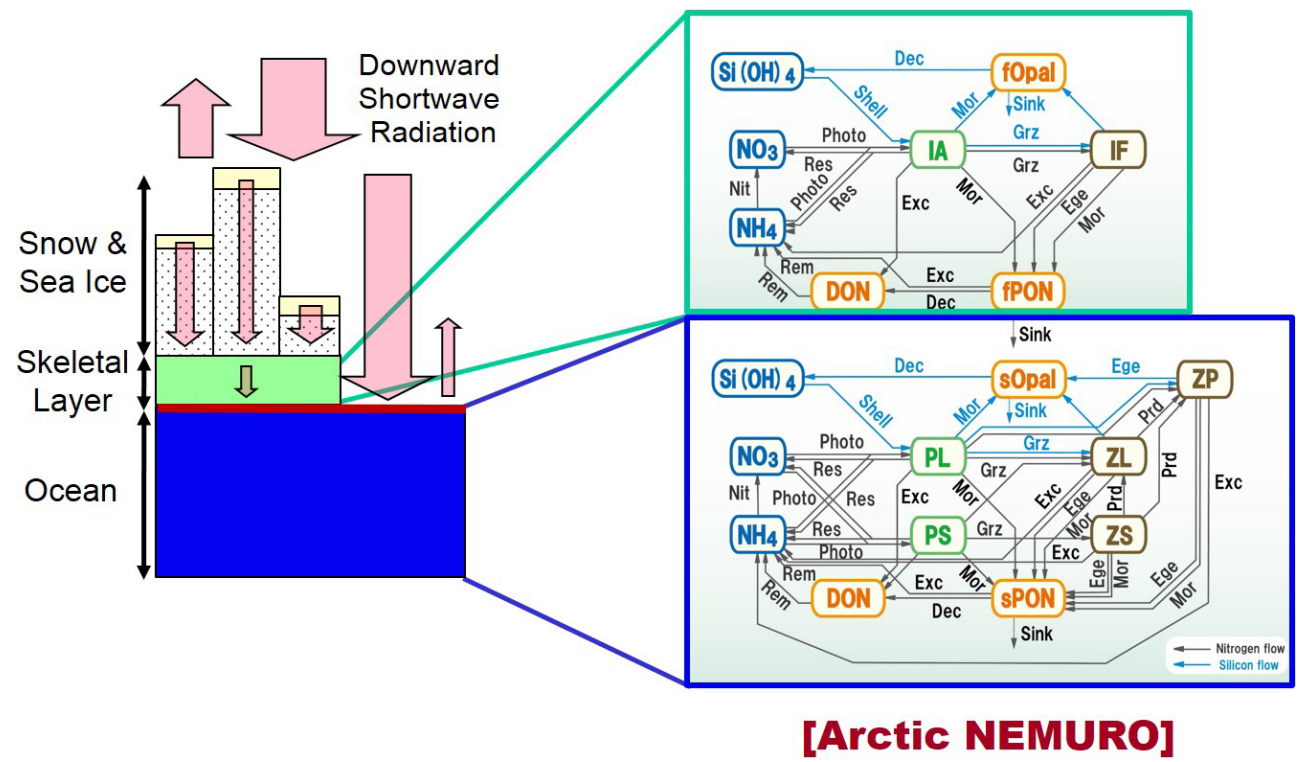

Figure 2. Schematic image and configuration of the Arctic NEMURO model. Nitrogen and silicon flows are composed of photosynthesis (Photo), shell formation (Shell), respiration (Res), excretion (Exc), mortality (Mor), grazing (Grz), predation (Prd), egestion (Ege), decomposition (Dec), remineralization (Rem), nitrification (Nit), and sinking (Sink). Ice algal habitat is confined to the skeletal layer of sea ice bottom. Ice-related fauna (IF) is calculated only in a sensitivity experiment (Case 4). Exchange of biogeochemical variables with the pelagic ecosystem is allowed at the ice-ocean interface.
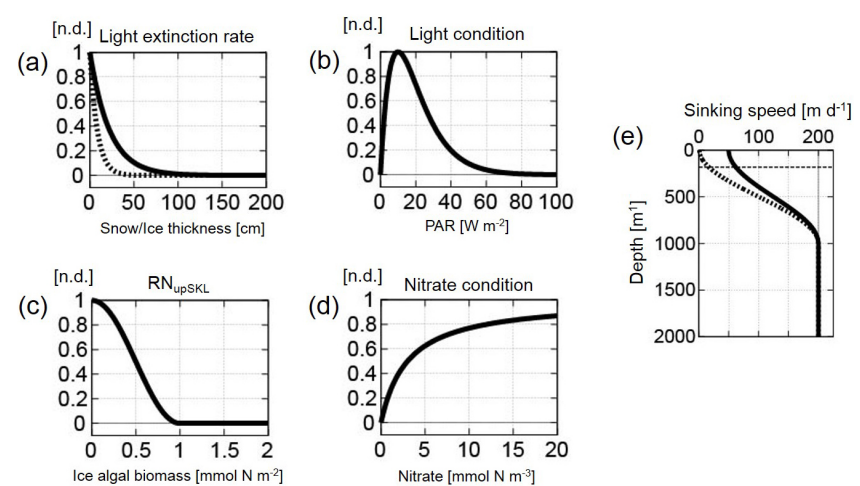

Figure 3. Relationships of (a) light extinction rate (nondimensional (n.d.)) vs. thickness of (dashed line) snow and (solid line) sea ice (cm), (b) light condition term (n.d.) vs. light intensity (PAR) $\left(\mathrm{W} \mathrm{m}^{-2}\right)$, (c) ice nutrient uptake ratio $\mathrm{RN}_{\text {upSKL }}$ (n.d.) vs. ice algal biomass $\left(\mathrm{mmol} \mathrm{N} \mathrm{m}^{-2}\right)$, (d) nitrate condition term (n.d.) vs. nitrate concentration $\left(\mathrm{mmol} \mathrm{N} \mathrm{m}^{-3}\right.$ ), and (e) sinking speed of PON derived from (solid line) ice algae and (dashed line) pelagic plankton groups $\left(\mathrm{m} \mathrm{d}^{-1}\right)$ vs. depth in the water column $(\mathrm{m})$, respectively, in the Arctic NEMURO model. See more information in Sect. 2.2.

set to $1 \mathrm{mmol} \mathrm{N} \mathrm{m}{ }^{-2}$ in the present experiments. As reported in Sect. 3.2, sea ice nutrients are consumed preferentially for the initial bloom of small-sized ice algae in early summer. According to the growth of ice algae, their nutrient source shifts to seawater for the mature period. The "hybrid-type" formulation of nutrient uptake represents more realistic ice algal biology, where ice algae anchoring under ice floes gradually raise meter-long filaments in the water column (Boetius et al., 2013). In each model time step, the Michaelis-Menten relationship is applied to nutrient concentration in the skeletal layer and in the ocean surface layer (i.e., the uppermost ocean grid), respectively (Fig. 3d):

$$
\begin{aligned}
& N_{\mathrm{upSKL}}=\min \left\{\mathrm{NO}_{3 \mathrm{SKL}} /\left(\mathrm{NO}_{3} \mathrm{SKL}+K_{\mathrm{NO}_{3}}\right)\right. \\
& \left.\times \exp \left(-\Psi_{\mathrm{NH}_{4}} \times \mathrm{NH}_{4} \mathrm{SKL}\right)\right\} \\
& \left.+\mathrm{NH}_{4} \mathrm{SKL} /\left(\mathrm{NH}_{4} \mathrm{SKL}+K_{\mathrm{NH}_{4}}\right), \mathrm{SIL}_{\mathrm{SKL}} /\left(\mathrm{SIL}_{\mathrm{SKL}}+K_{\mathrm{SIL}}\right)\right\} \\
& N_{\mathrm{upOCN}}=\min \left\{\mathrm{NO}_{3} \mathrm{OCN} /\left(\mathrm{NO}_{3} \mathrm{OCN}+K_{\mathrm{NO}_{3}}\right)\right. \\
& \left.\times \exp \left(-\Psi_{\mathrm{NH}_{4}} \times \mathrm{NH}_{4} \mathrm{OCN}\right)\right\} \\
& \left.+\mathrm{NH}_{4} \mathrm{OCN} /\left(\mathrm{NH}_{4} \mathrm{OCN}+K_{\mathrm{NH}_{4}}\right), \mathrm{SIL}_{\mathrm{OCN}} /\left(\mathrm{SIL}_{\mathrm{OCN}}+K_{\mathrm{SIL}}\right)\right\}
\end{aligned}
$$

where the constant coefficients of half saturation for nitrate $\left(K_{\mathrm{NO}_{3}}\right)$, ammonium $\left(K_{\mathrm{NH}_{4}}\right)$, and silicate $\left(K_{\mathrm{SIL}}\right)$ and of ammonium inhibition $\left(\Psi_{\mathrm{NH}_{4}}\right)$ have the same values (Table 1) as those of pelagic diatoms (i.e., large phytoplankton PL in the NEMURO model) (Kishi et al., 2007).

The ice algal biomass decreases due to mortality, grazing, and sea ice melting. The respiration and mortality terms are functions of the ice algal biomass itself (under the freezing temperature assumption). In the present experiments, there is no biomass of ice-related fauna, and the grazing pressure on ice algae is neglected except for a sensitivity experiment in Sect. 5.4. All ice algae are included in ice-derived PON without any biological activities after their export into the water column by melting sea ice. Sea ice assemblages sink 
Table 1. Parameters in the sea ice ecosystem model. The values of ice algae are same as those of large phytoplankton in the original NEMURO model (Kishi et al., 2007). The PAR fraction followed Zhang et al. (2010), and the light extinction rates were derived from Aota and Ishikawa (1982). The parameter values of nitrogen and silicon flows in the skeletal layer were same as those in the water column, which were also provided by Kishi et al. (2007).

\begin{tabular}{|c|c|c|c|}
\hline Parameter & Definition & Value & Unit \\
\hline \multicolumn{4}{|l|}{ [Ice algae] } \\
\hline$V_{\max }$ & Maximum phytosynthetic rate at $0^{\circ} \mathrm{C}$ & 0.8 & $\mathrm{~d}^{-1}$ \\
\hline$K_{\mathrm{NO}_{3}}$ & Half saturation constant for nitrate & 3.0 & $\mathrm{mmol} \mathrm{N} \mathrm{m}^{-3}$ \\
\hline$K_{\mathrm{NH}_{4}}$ & Half saturation constant for ammonium & 0.1 & $\mathrm{mmol} \mathrm{N} \mathrm{m}{ }^{-3}$ \\
\hline$K_{\mathrm{SIL}}$ & Half saturation constant for silicate & 6.0 & $\mathrm{mmol} \mathrm{N} \mathrm{m}{ }^{-3}$ \\
\hline$\Psi_{\mathrm{NH}_{4}}$ & Ammonium inhibition coefficient & 1.5 & $\left.(\mathrm{mmol} \mathrm{N} \mathrm{m})^{-3}\right)^{-1}$ \\
\hline $\mathrm{KN}_{\text {upSKL }}$ & Threshold value of ice/water nutrient uptake & 1.0 & $\mathrm{mmol} \mathrm{N} \mathrm{m}^{-2}$ \\
\hline$K_{\mathrm{Gpp}}$ & Temperature coefficient for photosynthetic rate & 0.0693 & ${ }^{\circ} \mathrm{C}^{-1}$ \\
\hline$I_{\text {opti }}$ & Optimum light intensity & 10 & $\mathrm{~W} \mathrm{~m}^{-2}$ \\
\hline $\operatorname{Res}_{0}$ & Respiration rate at $0^{\circ} \mathrm{C}$ & 0.03 & $\mathrm{~d}^{-1}$ \\
\hline$K_{\text {Res }}$ & Temperature coefficient for respiration rate & 0.0519 & ${ }^{\circ} \mathrm{C}^{-1}$ \\
\hline$\gamma$ & Extracellular excretion ratio to photosynthesis & 0.135 & n.d. \\
\hline $\operatorname{Mor}_{0}$ & Mortality rate at $0^{\circ} \mathrm{C}$ & 0.029 & $\left.(\operatorname{mmol~N~m})^{-3}\right)^{-1} \mathrm{~d}^{-1}$ \\
\hline$K_{\text {Mor }}$ & Temperature coefficient for mortality rate & 0.0693 & ${ }^{\circ} \mathrm{C}^{-1}$ \\
\hline$R_{\mathrm{SiN}}$ & $\mathrm{Si}: \mathrm{N}$ ratio & 2.0 & n.d. \\
\hline$V_{\text {fPONmin }}$ & Minimum sinking speed of ice-derived PON & 50 & $\mathrm{md}^{-1}$ \\
\hline \multicolumn{4}{|l|}{ [Light property] } \\
\hline PAR $_{\text {frac }}$ & Fraction of PAR to shortwave radiation & 0.43 & n.d. \\
\hline$k_{\text {snow }}$ & Light extinction rate for snow & 0.12 & $\mathrm{~cm}^{-1}$ \\
\hline$k_{\text {ice }}$ & Light extinction rate for sea ice & 0.045 & $\mathrm{~cm}^{-1}$ \\
\hline \multicolumn{4}{|l|}{ [Nitrogen/Silicon flow] } \\
\hline $\mathrm{Nit}_{0}$ & Nitrification rate at $0^{\circ} \mathrm{C}$ & 0.03 & $\mathrm{~d}^{-1}$ \\
\hline$K_{\mathrm{Nit}}$ & Temperature coefficient for nitrification & 0.0693 & ${ }^{\circ} \mathrm{C}^{-1}$ \\
\hline $\mathrm{VP} 2 \mathrm{~N}_{0}$ & Decomposition rate from $\mathrm{PON}$ to ammonium at $0^{\circ} \mathrm{C}$ & 0.1 & $d^{-1}$ \\
\hline $\mathrm{VP} 2 \mathrm{D}_{0}$ & Decomposition rate from $\mathrm{PON}$ to $\mathrm{DON}$ at $0^{\circ} \mathrm{C}$ & 0.1 & $\mathrm{~d}^{-1}$ \\
\hline $\mathrm{VD} 2 \mathrm{~N}_{0}$ & Decomposition rate from $\mathrm{DON}$ to ammonium at $0^{\circ} \mathrm{C}$ & 0.02 & $d^{-1}$ \\
\hline $\mathrm{VP} 2 \mathrm{Si}_{0}$ & Decomposition rate from opal to silicate at $0^{\circ} \mathrm{C}$ & 0.1 & $d^{-1}$ \\
\hline$K_{\mathrm{P} 2 \mathrm{~N}} / K_{\mathrm{P} 2 \mathrm{D}} / K_{\mathrm{D} 2 \mathrm{~N}} / K_{\mathrm{P} 2 \mathrm{Si}}$ & Temperature coefficient for decomposition rate & 0.0693 & ${ }^{\circ} \mathrm{C}^{-1}$ \\
\hline
\end{tabular}

faster than other particles derived from pelagic plankton because ice algae aggregate before the release from the sea ice bottom. Boetius et al. (2013) indicated rapid sinking of ice-related species. Hence, the modeled PON is divided into two components with different sinking speeds. The sinking speeds of PON derived from ice algae (pelagic plankton) are from 50-200 $\mathrm{m} \mathrm{d}^{-1}\left(2-200 \mathrm{~m} \mathrm{~d}^{-1}\right)$, following a cosine curve (Fig. 3e). The sinking speed is maintained at $200 \mathrm{~m} \mathrm{~d}^{-1}$ below a depth of $1000 \mathrm{~m}$. These profiles are reasonable, because sinking of particulate organic materials generally accelerates with depth due to particle densification processes (e.g., aggregation in shallow depths and elimination of light/fragile organic materials at middle depths) (Honda et al., 2013). The modeled OPL is treated in the same manner. We refer to the fast- and slow-sinking PON/OPL as fPON/fOPL and sPON/sOPL, respectively.
The horizontal advection of biogeochemical variables in the sea ice component is also calculated, as the Arctic NEMURO is implemented in a three-dimensional framework. The divergence (convergence) of sea ice velocity causes loss (accumulation) of each material as well as snow and ice volumes. The actual ridging process is accompanied by complex deformation, whereas the modeled sea ice ecosystem is kept consistently in the skeletal layer with a constant $2 \mathrm{~cm}$ thickness for simplicity.

\subsection{Experimental design}

The model domain contains the entire Arctic Ocean, the Greenland, Iceland and Norwegian seas, and the northern part of the North Atlantic (Fig. 1). The horizontal resolution is $5 \mathrm{~km}$, and there are $1400 \times 1000$ grid points. There are 42 hybrid $\sigma-z$ vertical levels. Vertical resolution varies 
from $2 \mathrm{~m}$ at the top to $500 \mathrm{~m}$ at the bottom. The $\sigma$-coordinate composed of three levels is applied to the uppermost $10 \mathrm{~m}$. We performed two 1-year experiments (called the 2011 and 2012 cases), in which the $5 \mathrm{~km}$ grid model was integrated from October 2010 (2011) to September 2011 (2012) to examine seasonal and interannual variability in ice algae. The initial sea ice and ocean physical fields for these experiments were obtained from a 1979-2011 decadal experiment using the $25 \mathrm{~km}$ grid version (Onodera et al., 2015). The atmospheric forcing components were constructed from the National Centers for Environmental Prediction/Climate Forecast System Reanalysis (NCEP/CFSR) 6-hourly data set (Saha et al., 2010). Pacific water inflow is provided at the Bering Strait, based on Woodgate et al. (2005). Following our previous modeling study (e.g., Watanabe, 2011), the idealized seasonal cycles of northward velocity, temperature, and salinity are prescribed such that the annual mean inflow is $0.8 \mathrm{~Sv}\left(1 \mathrm{~Sv} \equiv 10^{6} \mathrm{~m}^{3} \mathrm{~s}^{-1}\right)$ and temperature (salinity) reaches a maximum in September (March). Monthly nitrate and silicate concentrations derived from the World Ocean Atlas 2013 (Garcia et al., 2013) are used for a restoring along the lateral boundary region of the model domain, and summer climatology is assigned for the initial fields of ocean nutrients. As PON and opal in sea bottom sediments are crucial nutrient sources for the Arctic shelves via decomposition and remineralization processes, the fluxes in ammonium, DON, and silicate are added to the deepest layers just above the shelf bottom as in Watanabe et al. (2014). Sea ice nutrients are initially non-existent in the skeletal layer, and the lowest ice algal concentration of $0.02 \mathrm{mmol} \mathrm{N} \mathrm{m}^{-3}$ is given for initial growth (i.e., seeding). The relationship of $1 \mathrm{mmol} \mathrm{N}=80 \mathrm{mgC}=1.6 \mathrm{mgChl}$ is assumed using a $\mathrm{C} / \mathrm{Chl}$ mass ratio of 50 and a $\mathrm{C} / \mathrm{N}$ Redfield ratio of 6.625 to compare the model outputs with observational estimates, as in Watanabe et al. (2012). The detailed designs for sensitivity experiments are described in Sect. 5.

\subsection{Sediment trap analysis}

The bottom-tethered sediment traps (SMD26S-6000, NiGK Cooperation) have been moored at Station NAP $\left(75^{\circ} \mathrm{N}\right.$, $162^{\circ} \mathrm{W}, 1975 \mathrm{~m}$ water depth) since October 2010. Deployment and turnaround were conducted by the Japanese R/V Mirai and the Canadian Coast Guard Ship Sir Wilfrid Laurier. Sinking particles were sampled at depths of 181-218 m (median, $184 \mathrm{~m}$ ) during the first year from 4 October 2010 to 27 September 2011. The trap depth was $247-319 \mathrm{~m}$ (median, $256 \mathrm{~m}$ ) during the second year from 4 October 2011 to 17 September 2012. These sediment traps collected 26 samples approximately every 2 weeks during their 1-year deployment. The recovered trap samples were sieved through $1 \mathrm{~mm}$ mesh to remove swimmers, and particles $<1 \mathrm{~mm}$ were divided evenly into 10 sub-samples. One of 10 aliquot samples was filtered, and was desalted using Milli-Q water. The dried sample was weighed, and it was then ground and mixed using an agate mill. PON and POC contents were analyzed in one sequence. The powdered samples were decalcified in hydrochloric acid vapor in a desiccator for $8 \mathrm{~h}$ to remove particulate inorganic carbon. Sodium hydroxide pellets were placed in the desiccator to neutralize the samples. PON content in the treated samples was sequentially analyzed by a CHN analyzer (NCS2500, Thermo Quest). Sinking PON flux was calculated based on PON content, sampling period, open area of the sediment trap $\left(0.5 \mathrm{~m}^{2}\right)$, and aliquot size of the treated sample (1/10). The detailed analysis method and diatom valve fluxes were described in Onodera et al. (2015). The structures of radiolarians and copepods captured in the same traps were reported in Ikenoue et al. (2015) and Matsuno et al. (2015), respectively.

\section{Seasonal transition in the Chukchi Borderland}

\subsection{Physical environments}

We defined the NAP region as that enclosed by $74-76^{\circ} \mathrm{N}$ and $159-165^{\circ} \mathrm{W}$ for the following analyses (Fig. 1). Monthly mean values of the NCEP/CFSR cloud fraction, downward shortwave radiation, wind speed at a height of $10 \mathrm{~m}$, snow depth, sea ice thickness, and sea ice concentration averaged in the NAP region are summarized in Table 2. The modeled physical variables were evaluated (Fig. 4). The NAP region was entirely covered by sea ice during the winter and spring seasons from December to April, and sea ice concentration decreased gradually from May to September in both the 2011 and 2012 cases (Fig. 4a). The area-mean sea ice thickness reached approximately $200 \mathrm{~cm}$ in April (Fig. 4b), which is a typical value north of the Chukchi Sea (Haas et al., 2010). The declines in sea ice concentration and thickness were consistent with the sea ice melting period from May to September (Fig. 4c). The mechanical divergence of sea ice flow fluctuated within the range of $\pm 0.2 \mathrm{~d}^{-1}$ in early winter and late summer (Fig. 4d).

Compared with the sea ice conditions simulated in the 2011 case, the early-winter covering of sea ice was somewhat delayed in the 2012 case. Although sea ice continued to melt until mid-November, winter sea ice thickness was greater in the 2012 case. The anomalous wind pattern could account for thicker ice transport toward the NAP region, as suggested in Sect. 4.1. The negative anomaly of sea ice thickness in the 2011 case was additionally caused by two melting events in November and December (Fig. 4c) and the blanket effect of more snow accumulation on top of the sea ice (not shown). The faster rate of sea ice decline caused earlier sea ice opening in the 2012 case (Fig. 4a-b), partly due to lower surface albedo from less snow cover. These snow and sea ice differences were compatible with the NCEP/CFSR data (Table 2). In addition, the enhanced mechanical divergence of sea ice flow from mid-July to August accelerated the sea ice reduction in 2012 (Fig. 4d). Ice algal biomass in a specific region 


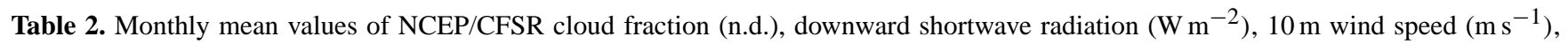
snow depth $(\mathrm{cm})$, sea ice thickness (cm), and sea ice concentration (n.d.) averaged in the NAP region. 2011 (2012) corresponds to the period from October 2010 (2011) to September 2011 (2012) to compare the model results.

\begin{tabular}{lrrrrrrrrrrrrr}
\hline & & Oct & Nov & Dec & Jan & Feb & Mar & Apr & May & Jun & Jul & Aug & Sep \\
\hline Cloud & 2011 & 0.98 & 0.87 & 0.79 & 0.79 & 0.91 & 0.88 & 0.72 & 0.90 & 0.76 & 0.92 & 0.98 & 0.96 \\
Fraction & 2012 & 0.94 & 0.90 & 0.67 & 0.81 & 0.79 & 0.56 & 0.61 & 0.83 & 0.88 & 0.97 & 0.97 & 0.96 \\
\hline Shortwave & 2011 & 9 & 0 & 0 & 0 & 4 & 51 & 165 & 236 & 305 & 217 & 102 & 45 \\
Radiation & 2012 & 10 & 0 & 0 & 0 & 4 & 62 & 170 & 245 & 264 & 184 & 92 & 46 \\
\hline Wind & 2011 & 6.7 & 5.1 & 5.0 & 5.1 & 6.0 & 4.3 & 4.6 & 4.4 & 4.5 & 4.4 & 5.3 & 5.4 \\
Speed & 2012 & 8.1 & 5.0 & 4.8 & 5.1 & 4.7 & 4.5 & 4.1 & 3.9 & 4.7 & 4.7 & 7.1 & 7.1 \\
\hline Snow & 2011 & 11 & 23 & 32 & 37 & 41 & 44 & 46 & 33 & 0 & 0 & 0 & 0 \\
Depth & 2012 & 8 & 23 & 22 & 21 & 23 & 23 & 22 & 13 & 0 & 0 & 0 & 0 \\
\hline Sea Ice & 2011 & 60 & 209 & 216 & 261 & 276 & 281 & 268 & 249 & 228 & 169 & 78 & 0 \\
Thickness & 2012 & 60 & 210 & 232 & 271 & 279 & 278 & 286 & 259 & 207 & 141 & 62 & 0 \\
\hline Sea Ice & 2011 & 0.21 & 0.89 & 0.98 & 0.99 & 0.99 & 0.99 & 0.99 & 0.99 & 0.99 & 0.83 & 0.19 & 0 \\
Concentration & 2012 & 0.19 & 0.90 & 0.98 & 0.98 & 0.98 & 0.98 & 0.99 & 0.97 & 0.87 & 0.70 & 0.18 & 0 \\
\hline
\end{tabular}

(a)

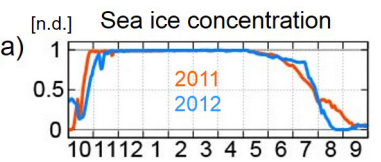

$\left[\mathrm{cm} \mathrm{d}^{-1}\right]$ Sea ice growth rate

(c)
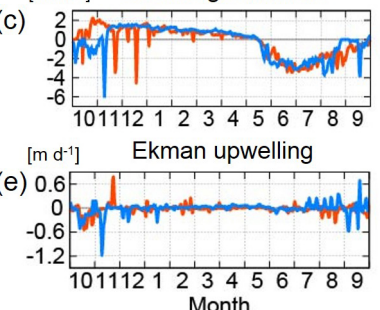

Figure 4. Seasonal transition of daily mean modeled variables in the NAP region. (a) Sea ice concentration (n.d.), (b) sea ice thickness $(\mathrm{cm}),(\mathbf{c})$ thermal growth rate of sea ice $\left(\mathrm{cm} \mathrm{d}^{-1}\right),(\mathbf{d})$ divergence of sea ice velocity $\left(\mathrm{d}^{-1}\right)$, (e) Ekman upwelling velocity diagnosed using ocean surface stress fields $\left(\mathrm{m} \mathrm{d}^{-1}\right)$, and (f) vertical diffusivity at the depth of $20 \mathrm{~m}\left(\mathrm{~cm}^{2} \mathrm{~s}^{-1}\right)$ in the 2011 (red line) and 2012 (blue line) cases. Note that negative values in (c), (d), and (e) correspond to sea ice melting, convergence of sea ice velocity, and Ekman downwelling, respectively. Vertical diffusivity in (f) is shown in a logarithm scale.

can change based on sea ice divergence events. The detailed processes associated with cyclone activities are discussed in Sect. 4.4 .

As ice algal primary production depends highly on nutrient conditions in the underlying ocean surface layer, replenishment of nitrate and silicate from depths in the nutricline is substantially important. The Ekman upwelling and downwelling velocities were calculated from the modeled ocean surface stress fields (i.e., the combination of wind stress in open water area and ice-ocean stress under sea ice). The week-long Ekman downwelling occurred in both cases during the winter, as usually seen inside the Beaufort Sea (Yang, 2009), and a strong upwelling event appeared in the 2011 case (Fig. 4e). In July-August, the Ekman velocity sign was opposite between the two cases. The mid-summer Ekman downwelling (upwelling) played a role in the nutricline deepening (shoaling) in the 2011 (2012) case. The vertical turbulent mixing was characterized by vertical diffusivity diagnosed using the closure scheme of Noh and Kim (1999) in the present model. Turbulent mixing was activated during winter in the 2011 case (Fig. 4f). During the other periods, the smaller values of modeled vertical diffusivity by 1 or 2 orders of magnitude indicated that the mixing process had a relatively minor impact on nutrient entrainment in the NAP region.

\subsection{Ice algal production}

The modeled ice algal production demonstrated remarkable spatial and interannual variability in the western Arctic Ocean (Fig. 5). Annual production exceeded $0.6 \mathrm{mmol} \mathrm{N} \mathrm{m}^{-2}$ over most of the Chukchi Sea shelf, whereas low productivity $<0.1 \mathrm{mmol} \mathrm{N} \mathrm{m}^{-2}$ was located in the central Canada Basin. The shelf-basin contrast in ice algal production was previously detected by the trans-Arctic Ocean expedition in the 1990s (Gosselin et al., 1997) and represented by decadal model simulations (Jin et al., 2012; Dupont, 2012). In the 2011 case, the local maximum appeared north of the Chukchi and Beaufort shelf breaks (Fig. 5a), whereas ice algal productivity was suppressed considerably around the Beaufort Gyre region in the 2012 case (Fig. 5b). The negative anomaly widely covered the western Arctic except the coastal shelves and the northern part of Chukchi Border- 
land (Fig. 5c). Station NAP was located near the shelf-basin boundary and also showed the negative anomaly.

In the NAP region, the modeled ice algal bloom started in June and produced a peak biomass of $0.7 \mathrm{mmol} \mathrm{N} \mathrm{m}^{-2}$ at the beginning of August in the 2011 case (Fig. 6a). The peak timing was a few months later than the pan-Arctic averages simulated in previous models (Jin et al., 2012; Deal et al., 2011), partly because the NAP region is located north of highly productive shelves. An additional reason for the lagged peak phase may be attributed to a lower photosynthetic response to incoming solar irradiance in the present model setting. Sensitivity to optimum light intensity is shown in Sect. 5.1. The Hovmöller diagram visualized the vivid shelf-basin contrast along the $75^{\circ} \mathrm{N}$ line (Fig. 6b). The bloom signal was quite weak inside the Canada Basin. A massive ice algal bloom up to $10 \mathrm{mmol} \mathrm{N} \mathrm{m}^{-2}$ was simulated in July over the Chukchi northern shelf to the west of the NAP region. The modeled ice algal biomass north of the Chukchi Sea was within the lower range of $1-340 \mathrm{mgChl} \mathrm{m}^{-2}$ in Arctic sea ice (Arrigo et al., 2010) and 1 order of magnitude smaller than that measured in Resolute Passage $\left(160 \mathrm{mgChl} \mathrm{m}^{-2}\right.$; Michel et al., 1996). The Chukchi Borderland has shifted from a perennial ice-covered area to a seasonal ice zone in recent years. Multi-year ice would have dimmed the ice algal bloom in the past decades in this area. It is also reasonable that substantially lower amounts of nutrients restricted ice algal growth to the level below the pan-Arctic averages. In the 2012 case, initial bloom timing was further delayed by 1 month, and ice algal biomass was clearly smaller than that of the 2011 case (Fig. 6a, c).

As introduced in Sect. 2.2, ice algal production rate was calculated using the empirical functions of light condition and nutrient uptake terms. The light condition in the skeletal layer of the sea ice column was recovered slowly after the end of polar night (February in the NAP region) and then increased rapidly due to thinning of snow/ice in May (Fig. 7a). Peak values of PAR $\left(3.5 \mathrm{~W} \mathrm{~m}^{-2}\right.$ in the 2011 case, and $2.2 \mathrm{~W} \mathrm{~m}^{-2}$ in the 2012 case) were recorded in mid-July after the summer solstice. Although sea ice melting continued until September, light intensity turned to decrease in accordance with the annual cycle of solar radiation. As the optimal light intensity for ice algal growth $\left(I_{\mathrm{opti}}\right)$ was set to $10 \mathrm{~W} \mathrm{~m}^{-2}$ in the present experiments, the light condition term varied in phase with the PAR transition (Fig. 7b). The weaker summer light intensity in the 2012 case could be attributed to the depressed shortwave radiation due to more cloud cover (Table 2), despite thinner sea ice in August (Fig. 4b). The cyclone impact on light conditions is described in Sect. 4.4.

The nutrient conditions in the sea ice and water columns showed remarkable interannual variability. Sea ice nitrate content peaked at $0.6 \mathrm{mmol} \mathrm{N} \mathrm{m}^{-2}\left(0.2 \mathrm{mmol} \mathrm{N} \mathrm{m}^{-2}\right)$ in the 2011 (2012) case (Fig. 8a), which was 1 order of magnitude smaller than in landfast ice in Resolute Passage of the Canadian Archipelago (Cota and Smith, 1991). Potential fac- tors contributing to the difference include the nutrient environment in the underlying water column and the sea ice freezing rate, because nutrient accumulation in the skeletal layer was induced by ocean-to-ice flux during the sea ice freezing period (see formulation in Sect. 2.2). At the initial period of the 1-year model integration, the nutricline depth was located at $20 \mathrm{~m}$ in the NAP region (Fig. $8 \mathrm{~b}-\mathrm{c}$ ). Ekman downwelling helped deepen the nutricline from October to early November in both cases (Fig. 4e). In the 2011 case, Ekman upwelling was also evident in November. However, the duration was just 1 week, so the Ekman contribution with a peak of $0.8 \mathrm{~m} \mathrm{~d}^{-1}$ played a minor role in nutrient entrainment. The more important contributory process was strong mixing during winter in the 2011 case, as shown by the enhanced vertical diffusivity (Fig. 4f). According to these processes, the surface nitrate concentration reached $2 \mathrm{mmol} \mathrm{N} \mathrm{m}^{-3}$ (Fig. 8b), and a significant part was imported into the skeletal layer (Fig. 8a). In contrast, the oligotrophic water stayed over the nutricline, which was at a nearly constant depth or somewhat deepened during winter in the 2012 case (Fig. 8c). Sea ice nitrate content reflected the ocean surface value of $<1 \mathrm{mmol} \mathrm{N} \mathrm{m}^{-3}$. Sea ice silicate, which had a similar difference to nitrate, was not a limiting factor for ice algal growth in the NAP region (not shown). The rate of sea ice freezing also differed between the two cases. The total amount of thermal sea ice growth from October to April was 160 (136) $\mathrm{cm}$ in the 2011 (2012) cases. Whereas we focused on the seasonal transitions from winter to early summer, in situ data of nutrient concentration and sea ice freezing rate were unavailable for the target region and period. Accordingly, proper evaluations of the modeled properties, particularly during winter, were difficult at this stage. At least, the model results suggest that the nutrient accumulation in the skeletal layer during the freezing period controls the interannual variability in the initial ice algal bloom. The influences of the basin-scale wind pattern and water mass transport on the nutrient environment are analyzed in Sect. 4.

Nutrient availability for ice algal production reflected the difference in this preconditioning. Based on the present model formulation, sea ice nutrients were consumed primarily during an initial stage of the ice algal bloom, and nutrients in the ocean surface layer were utilized for further blooms. According to ice algal growth (Fig. 6a), the uptake ratio of sea ice nutrients $\left(\mathrm{RN}_{\text {upSKL}}\right)$ shifted from 1 to 0.7 within a few weeks of July in the 2011 case (Fig. 7c). When the half-saturation constant for nitrate uptake $\left(K_{\mathrm{NO}_{3}}\right)$ was set to $6 \mathrm{mmol} \mathrm{N} \mathrm{m}^{-3}$ for ice algae as well as pelagic diatoms (PL in the present model), the nitrate uptake term before the ice algal bloom was approximately $0.9(0.7)$ in the 2011 (2012) case (Fig. 7d). The growth ratio between the two cases became 1.8 at the beginning of June after multiplying the light condition term (Fig. 7b). The larger growth rate accounted for the earlier initial ice algal bloom in the 2011 case (Fig. 6a). Sea ice nitrate was depleted rapidly by this initial bloom and partially by export to the water column 

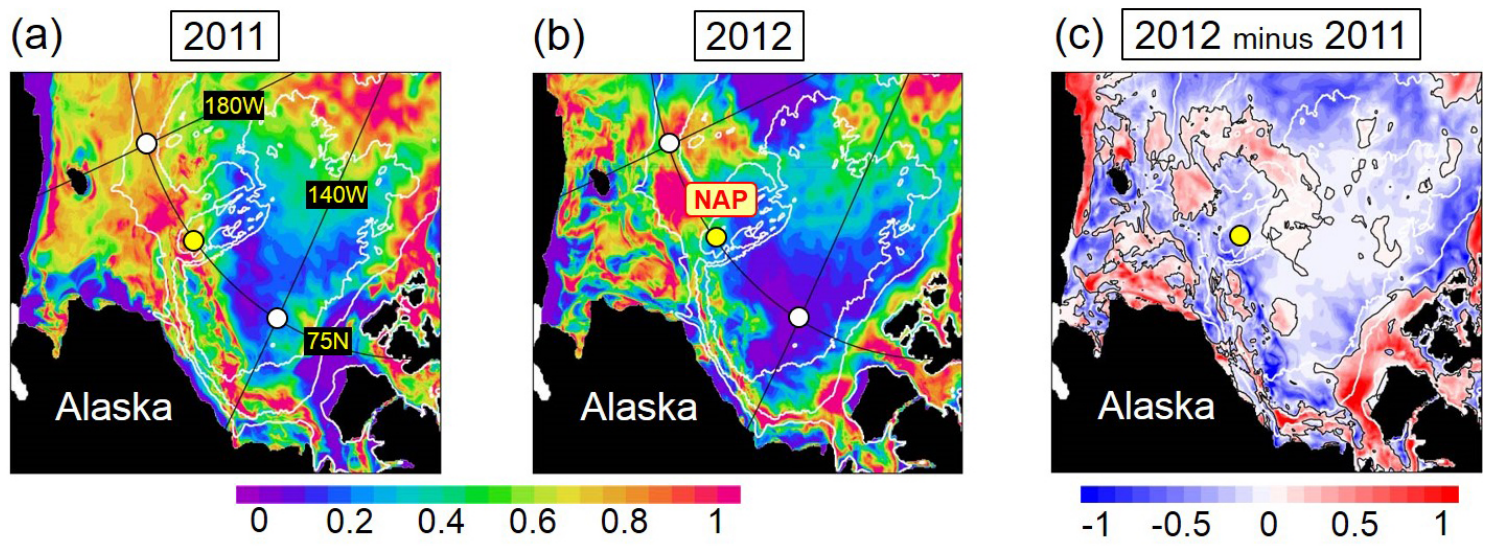

\section{Annual primary production of ice algae $\left[\mathrm{mmol} \mathrm{N} \mathrm{m}^{-2}\right]$}

Figure 5. Modeled annual primary production of ice algae in the (a) 2011 and (b) 2012 cases ( $\mathrm{mmol} \mathrm{N} \mathrm{m}^{-2}$ ). The difference between the two cases is shown in (c). Yellow dots denote the location of Station NAP. White dots represent the eastern and western limits of $75^{\circ} \mathrm{N}$ section in Fig. 6b-c.

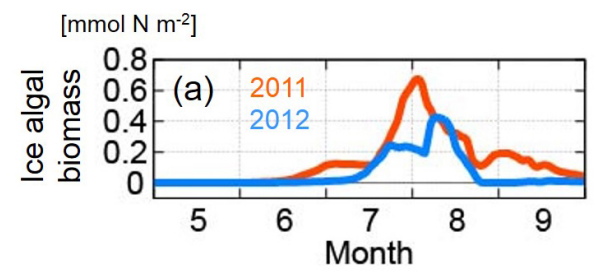

(b)
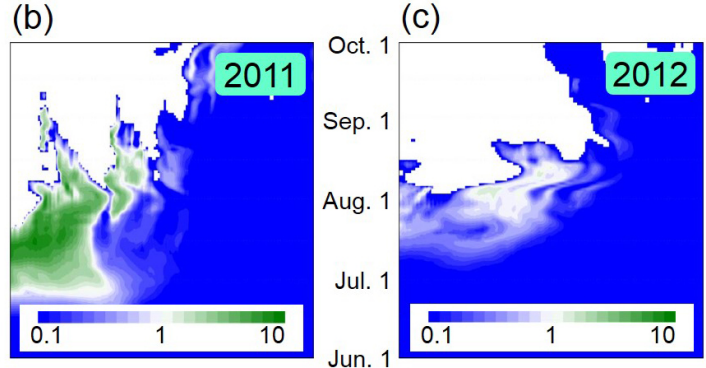

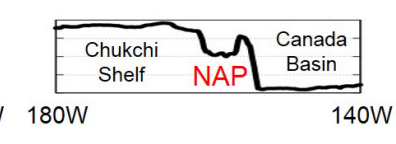

Figure 6. Modeled seasonal transition of ice algal biomass (a) in the NAP region and $(\mathbf{b}-\mathbf{c})$ along the $75^{\circ} \mathrm{N}$ line $\left(\mathrm{mmol} \mathrm{N} \mathrm{m}^{-2}\right)$. Sea floor depths along the east-west section are also plotted (m). Red line in (a) and Hovmöller diagram in (b) correspond to the 2011 case. Blue line in (a) and the diagram in (c) correspond to the 2012 case. The content of $1 \mathrm{mmol} \mathrm{N} \mathrm{m}^{-2}$ in the sea ice column corresponds to the concentration of $50 \mathrm{mmol} \mathrm{N} \mathrm{m}^{-3}$ when the skeletal layer thickness is set to $2 \mathrm{~cm}$.

with melting sea ice (Fig. 8a). The subsequent decrease in

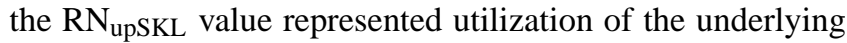
seawater nutrients (Fig. 7c). The additional bloom occurred in late July (Fig. 6a). In the 2012 case, the decrease in the nutrient uptake term lagged behind the 2011 case in accordance
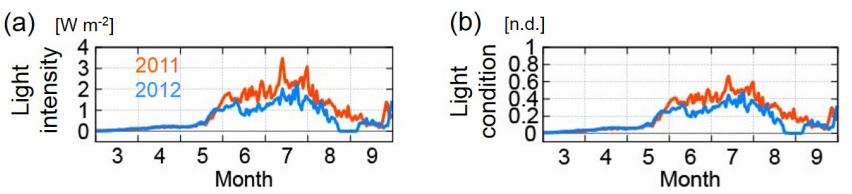

(c) [n.d.]
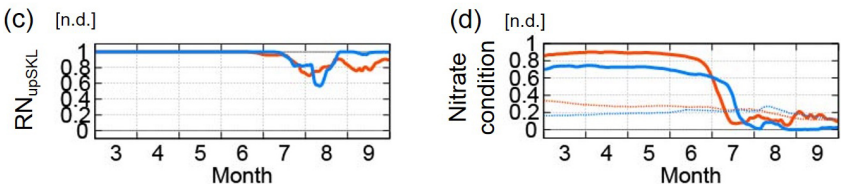

Figure 7. Modeled seasonal transition of (a) light intensity (PAR) in the skeletal layer $\left(\mathrm{W} \mathrm{m}^{-2}\right)$, (b) light condition term (n.d.), (c) ice nutrient uptake ratio $\mathrm{RN}_{\text {upSKL }}$ (n.d.), and (d) nitrate condition term (n.d.) in the NAP region in the 2011 (red line) and 2012 (blue line) cases. Each term in (b-d) corresponds to ice algal value. In (d), the condition terms in the (thick lines) skeletal layer and (thin lines) ocean surface layer are shown.

with the delay of the initial bloom (Fig. 7d). The ocean nutrient uptake term, which had lower values during the ice freezing period, gradually became comparable with the 2011 case. However, the higher $\mathrm{RN}_{\mathrm{upSKL}}$ value, except in early August, restricted ocean nutrient uptake in the 2012 case (Fig. 7c).

As expected, the seasonal transition of the ice algal biomass was similar to daily primary productivity (Fig. 9ab). In the present model experiments, primary production derived from nutrients in the skeletal layer and in the water column was calculated separately. In the 2011 case, the nutrient source for the ice algal bloom changed from the sea ice column for the first primary production peak of $23 \mu \mathrm{mol} \mathrm{N} \mathrm{m}{ }^{-2} \mathrm{~d}^{-1}$ to seawater for the second larger peak of $82 \mu \mathrm{mol} \mathrm{N} \mathrm{m}{ }^{-2} \mathrm{~d}^{-1}$. The second peak value of $\sim 6.6 \mathrm{mgC} \mathrm{m}^{-2} \mathrm{~d}^{-1}$ was close to the field-based 
(a) $[\mathrm{mmol} \mathrm{N} \mathrm{m}-2]$

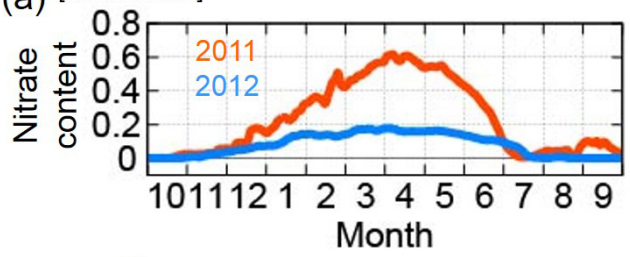

(b)

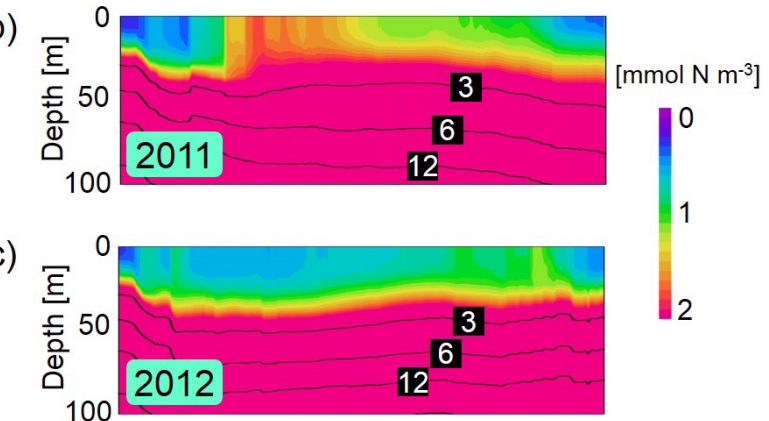

Figure 8. Modeled seasonal transition of nitrate concentration (a) in the skeletal layer $\left(\mathrm{mmol} \mathrm{N} \mathrm{m}^{-2}\right)$ and $(\mathbf{b}-\mathbf{c})$ in the top $100 \mathrm{~m}$ of water columns (mmol $\mathrm{N} \mathrm{m}^{-3}$ ). Red line in (a) and vertical profile in (b) correspond to the 2011 case. Blue line in (a) and the profile in (c) correspond to the 2012 case.

estimates of $4-9 \mathrm{mgC} \mathrm{m}^{-2} \mathrm{~d}^{-1}$ on the Beaufort shelf and slopes (Gradinger, 2009) and $<10 \mathrm{mgC} \mathrm{m}^{-2} \mathrm{~d}^{-1}$ in the Arctic basins (Deal et al., 2011). The model results indicate that nutrients imported by sea ice freezing determine the beginning of the ice algal bloom, and that ocean nutrients have a greater contribution to annual ice algal production, as reported previously (Gradinger, 2009). The comparison with the PON export to the underlying water column suggested that more than half of the organic nitrogen was remineralized in the sea ice column (Fig. 9a). In the 2012 case, the peak of primary production simulated in early August was $35 \mu \mathrm{mol} \mathrm{N} \mathrm{m} \mathrm{d}^{-2}$ (Fig. 9b). The relative contribution of ocean nutrients to primary productivity was less than that in the 2011 case. The August peak in PON export flux exceeding ice algal productivity was attributed to lateral advection of shelf-origin sea ice floes. Detailed discussions are presented in Sects. 4.3 and 4.4.

\section{Wind-driven dynamics associated with ice algal productivity}

To examine background mechanisms for year-to-year changes in ice algal productivity, wind-driven sea ice and ocean dynamics in the western Arctic Ocean were addressed.

\subsection{Wind and sea ice patterns}

Interannual variabilities in sea ice motion and ocean surface currents in the Beaufort Sea are closely related to the atmospheric circulation pattern (Yang, 2009; Proshutin-
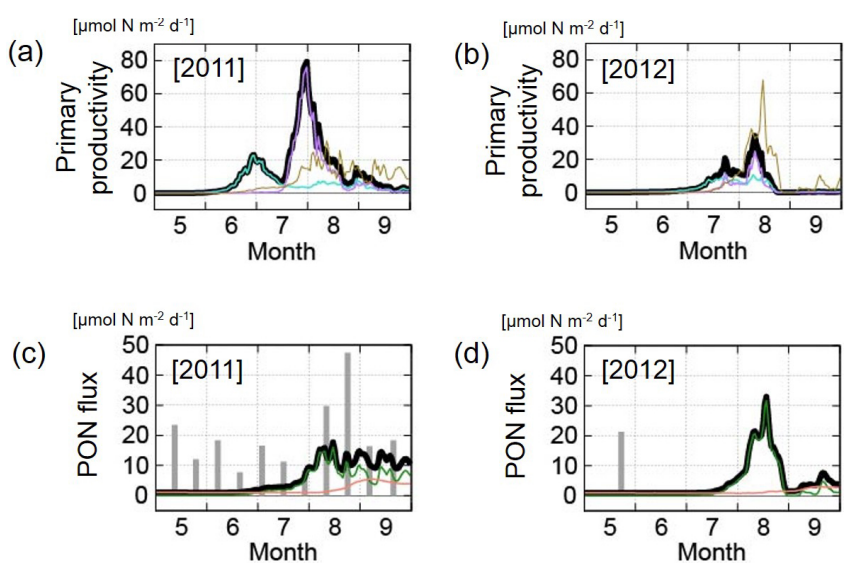

Figure 9. Modeled (a-b) primary production rate of ice algae and (c-d) PON flux in the NAP region in the (a, c) 2011 and (b, d) 2012 cases $\left(\mu \mathrm{mol} \mathrm{N} \mathrm{m} \mathrm{N}^{-2} \mathrm{~d}^{-1}\right)$. In $(\mathbf{a}-\mathbf{b})$, the daily rate of total primary production (black lines) and those derived from nutrients in the skeletal layer (light blue lines) and water column (purple lines) are shown. The export flux of PON from the sea ice bottom to the underlying water column is overlaid by olive lines. In (c-d), the total simulated (black lines) and observed (gray bars) PON fluxes at $180 \mathrm{~m}$ are compared. The fluxes originating from ice algae (green lines) and pelagic plankton groups (orange lines) are also shown.

sky et al., 2009). We compared the winter mean sea level pressure (SLP) and wind stress fields constructed from the NCEP/CFSR reanalysis data between the 2 years. Wind stress was calculated from the daily mean SLP using a protocol of the Arctic Ocean Model Intercomparison Project (AOMIP) (http://www.whoi.edu/page.do?pid= 30576). An anti-cyclonic wind pattern was accompanied by a weak Beaufort High around the Canada Basin during winter 2010-2011 (Fig. 10a). The easterly wind in the southern Beaufort Sea was favorable for transporting Chukchi shelf water toward the southern Canada Basin and the NAP region via the Ekman process. Ekman transport was analytically estimated with a seawater density of $1.025 \times 10^{3} \mathrm{~kg} \mathrm{~m}^{-3}$ and a Coriolis coefficient of $1.4 \times 10^{-4} \mathrm{~s}^{-1}$. A sea iceocean stress value of $0.1 \mathrm{~Pa}$, which was frequently recorded along the Chukchi shelf break during early winter in the 2011 case, yielded an Ekman transport value of $0.7 \mathrm{~m}^{2} \mathrm{~s}^{-1}$ $\left(1.8 \mathrm{~km}^{2} \mathrm{mon}^{-1}\right)$. This value is close to the November climatology in the southern Beaufort Sea (Yang, 2009) and indicates a shelf-basin water exchange of $900 \mathrm{~km}^{3} \mathrm{mon}^{-1}$ for a shelf break axis length of $500 \mathrm{~km}$. In contrast, high SLP extended from the Siberian Arctic to the western Arctic Ocean in winter 2011-2012 (Fig. 10b). Accordingly, a northwesterly wind prevailed in the Beaufort Sea. In this situation, no definite shelf water transport toward the NAP region was expected by the winter wind fields.

The changes in wind patterns were consistent with the modeled physical environments in the NAP region, where several differences between the 2011 and 2012 cases were 
(a)

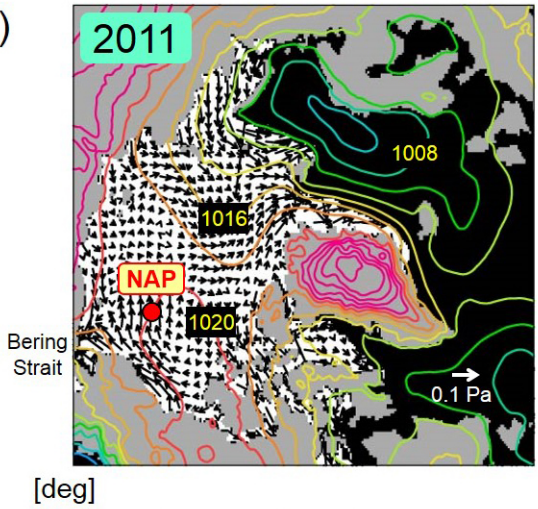

(c)

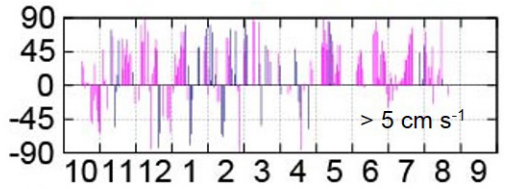

(e)

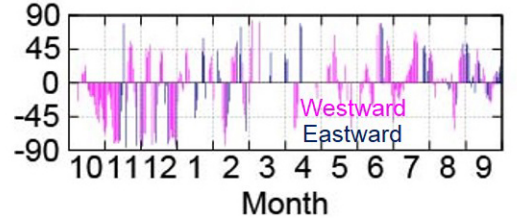

(b)

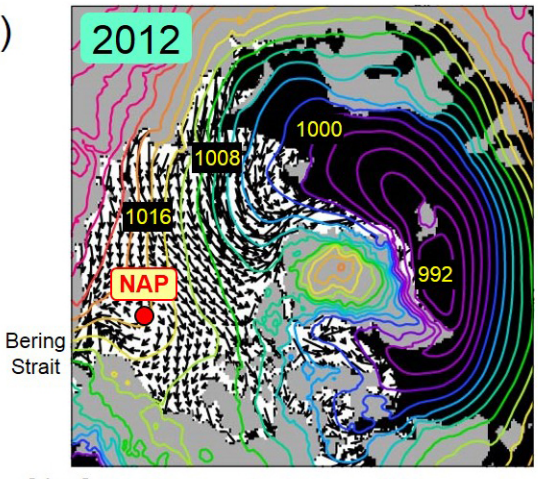

[deg]

(d)

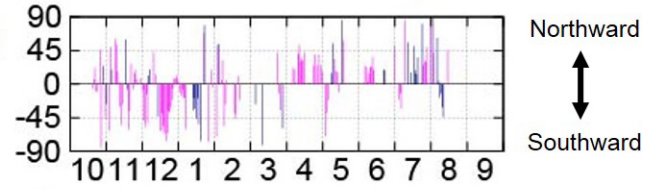

(f)

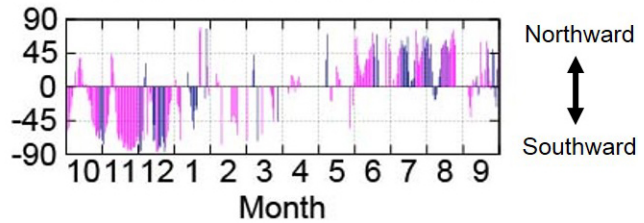

Figure 10. (a-b) (contours) Sea level pressure (SLP) (hPa) and (vectors) wind stress averaged (a) from November 2010 to January 2011 and (b) from November 2011 to January 2012. SLP is obtained from the NCEP/CFSR data set, and wind stress vectors are calculated from the SLP field using the AOMIP formulation. Unit vector of wind stress is $0.1 \mathrm{~Pa}$. Direction of (c-d) satellite-based and (e-f) modeled sea ice velocity in the NAP region (degree). Only daily averages whose velocity exceeded $5 \mathrm{~cm} \mathrm{~s}^{-1}$ in the (c, e) 2011 and (d, f) 2012 periods are plotted. Positive (negative) values of the direction correspond to northward (southward), and magenta (navy) bars indicate westward (eastward) motions, respectively. For example, a magenta bar of $-45^{\circ}$ means southwestward direction of $225^{\circ} \mathrm{T}$, where $0^{\circ} \mathrm{T}$ corresponds to true north.

described in Sect. 3.1. For October to early November 2011 (i.e., the beginning period of the 2012 case), localized anticyclonic wind forcing was closely related to the modeled negative rate of sea ice growth, convergence of sea ice velocity, and Ekman downwelling in the NAP region (Fig. 4c-e). The wind-driven warm water intrusion toward the marginal ice zone induced lateral/bottom melting of sea ice floes (not shown). Sea ice convergence increased sea ice thickness via mechanical ridging processes, in contrast to sea ice melting occurring during the same period. Continuous Ekman downwelling coincided with the sea ice convergence. For the period afterwards, the positive anomaly of sea ice thickness was produced by southward transport of thicker sea ice from the central Arctic in the 2012 case (Fig. 4b). The direction of sea ice flow around the NAP region clearly differed between the 2 years (Fig. 10c-f), as detected previously by satellite-based and modeled spatial patterns (Onodera et al., 2015). Both the daily time series in the Polar Pathfinder sea ice motion vectors (Fowler et al., 2013) and in the simulation results showed the successive southward advection of sea ice from late October 2011 to January 2012 (Fig. 10d, f). Sea ice moved several hundred $\mathrm{km}$ during this period when sea ice velocity was $5 \mathrm{~cm} \mathrm{~s}^{-1}$ (ca. $130 \mathrm{~km} \mathrm{mon}^{-1}$ ). These results suggest that the anomalous wind pattern forced southward transport of oligotrophic sea ice and water masses within the Beaufort Gyre and eventually reduced nutrient availability in the Chukchi Borderland.

\subsection{Nutrient and shelf-break tracer distributions}

The nutrient preconditioning that occurred before the ice algal blooming period reflected the wind-driven sea ice and water mass transport, as suggested in Sect. 4.1. The spatial distribution of the ocean nitrate concentration was characterized by a sharp meridional gradient across the Chukchi and Beaufort shelf breaks (Fig. 11a-b), as captured by a number of ship-based observations (e.g., Nishino et al., 2011). The modeled vertical average in the top $30 \mathrm{~m}$ reached $10 \mathrm{mmol} \mathrm{N} \mathrm{m}^{-3}$ in the central Chukchi Sea and was $<1 \mathrm{mmol} \mathrm{N} \mathrm{m}^{-3}$ in the Canada Basin. As shown in Fig. 8, nitrate content around the NAP region tended to differ. In the 2011 case, relatively high nitrate concentrations were distributed from the northern shelf of the Chukchi Sea to east of Northwind Ridge along $75^{\circ} \mathrm{N}$ (Fig. 11a). On the other hand, the shelf-basin contrast in nitrate content was still apparent even in the southern area of Chukchi Borderland in the 2012 case (Fig. 11b). 

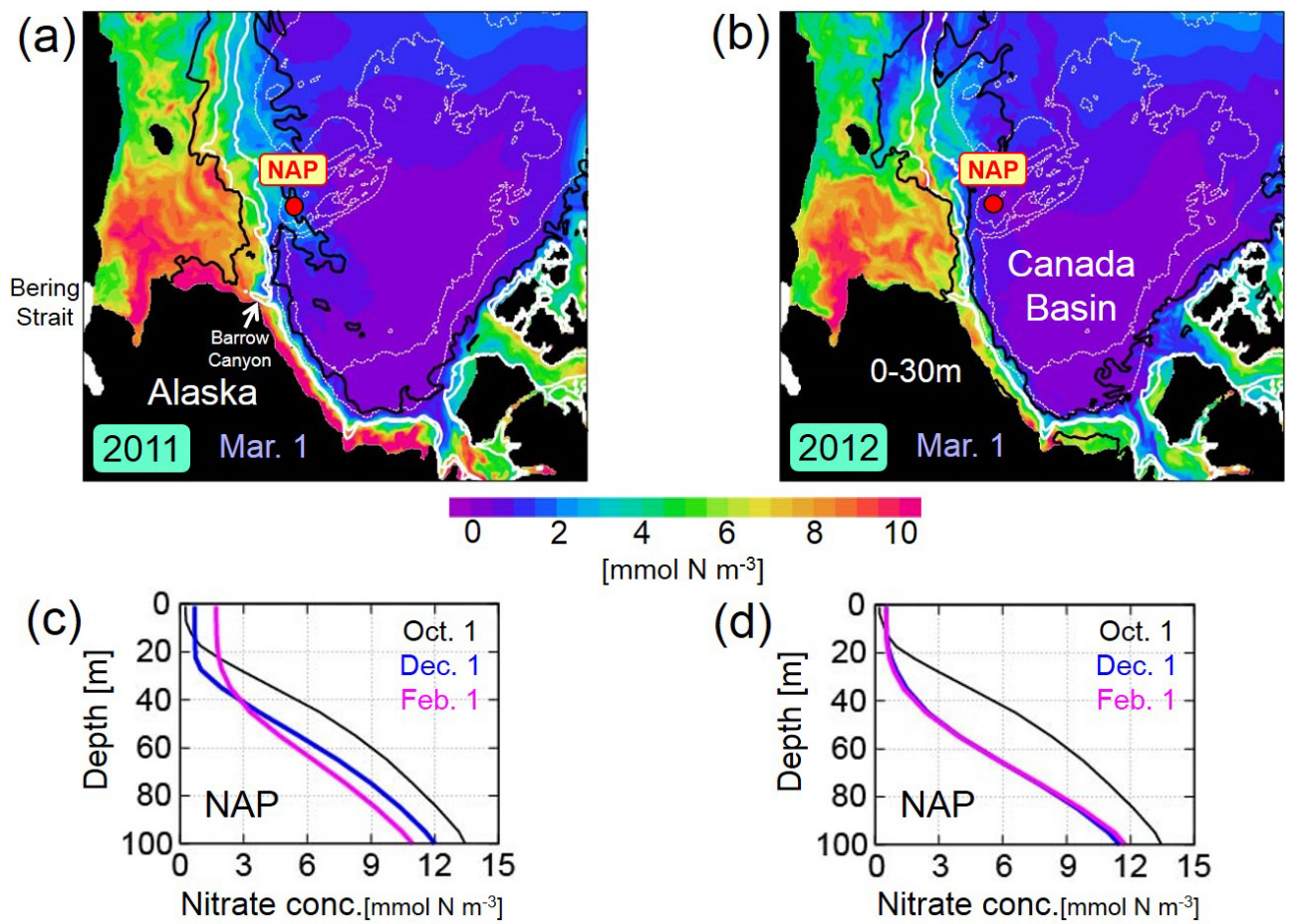

Figure 11. Modeled nitrate concentration $\left(\mathrm{mmol} \mathrm{N} \mathrm{m}^{-3}\right)$. The daily mean fields averaged in the top $30 \mathrm{~m}$ of water columns on $1 \mathrm{March}$ in the (a) 2011 and (b) 2012 cases are shown in the upper panels. In these experiments, a passive tracer is provided from the ocean surface to sea floor of 100-200 m depth along shelf-basin boundary sandwiched by thick white contours. Black contours correspond to a tracer value of $0.2(0-30 \mathrm{~m}$ average). Thin white contours denote the isobaths of 1000 and $3000 \mathrm{~m}$. The vertical profile in the NAP region on (black) 1 October, (blue) 1 December and (magenta) 1 February in the (c) 2011 and (d) 2012 cases are shown in the lower panels.

To explore the paths of the shelf-break water, a virtual passive tracer was provided along the shelf-basin boundary. We chose the tracer source region sandwiched between the $100-200 \mathrm{~m}$ isobaths. The tracer value was fixed at 1.0 (i.e., $100 \%$ concentration) for depths of $0-200 \mathrm{~m}$ in the defined region through each 1-year experiment. Advection and diffusion of the tracer in the other regions were calculated as well as seawater temperature and salinity. The modeled distribution in March 2011 indicated that the tracer provided along the shelf-basin boundary region was transported from the Chukchi northern shelf toward the interior of the Canada Basin. The northern edge of the tracer matched the nitraterich area in the 2011 case (Fig. 11a). The vertical profile of nitrate concentration in the NAP region reflected the deepening nutricline driven by the Ekman downwelling in October (Figs. 4e and 11c). Subsequently, nitrate content in the upper $50 \mathrm{~m}$ showed a net increase during December-January, which could be explained by lateral input rather than local vertical mixing. Hence, the model results indicate that Ekman transport of Chukchi shelf water along with energetic turbulent mixing enhanced nutrient availability for ice algae in the NAP region. In contrast, in March 2012, the tracer signal was quite weak over the Chukchi Borderland (Fig. 11b). No significant change occurred in the vertical nitrate profile during winter after the wind-driven downward shift (Fig. 11d). The spread of fresher basin water blocked the intrusion of shelf water and weakened the turbulent mixing. The density stratification plausibly controlled ocean subsurface mixing, as wind speed averaged from November to January of the 2011 and 2012 winter periods was comparable (Table 2). This mechanism was consistent with previous findings, in which the mixed layer depth correlated with hydrographic structures rather than wind forcing in the western Arctic (Peralta-Ferriz et al., 2015).

Onodera et al. (2015) categorized the sinking diatom assemblages in the sediment trap samples at Station NAP into 98 taxa. The dominant species during summer 2011 were Fossula arctica and the Fragilariopsis group (F. cylindrus and $F$. oceanica), which are common in ice algae in the shelf region (Cremer, 1999). Their relative abundances were minor in the sinking diatom flora during summer 2012. Instead, the major diatoms in August 2012 were planktonic species such as Thalassionema nitzschioides, which was commonly observed in the Canada Basin. In addition, the sinking flux of total diatom valves in August 2012 was considerably lower than that in August 2011. The observed diatom compositions and valve fluxes were consistent with the above-mentioned physical backgrounds. The modeled nitrate distribution and tracer pathway supported the suggestion that winter transport of oligotrophic water from the interior of the Canada Basin 
toward the NAP region was an important factor suppressing ice algal productivity during summer 2012 .

\subsection{PON flux}

The time series of sinking PON flux in the NAP region was compared with the sediment trap data. The modeled PON flux at $180 \mathrm{~m}$ in the 2011 case increased gradually from June and peaked at $18 \mu \mathrm{mol} \mathrm{N} \mathrm{m}{ }^{-2} \mathrm{~d}^{-1}$ in mid-August following the ice algal bloom (Fig. 9c). Flux $>8 \mu \mathrm{mol} \mathrm{N} \mathrm{m}{ }^{-2} \mathrm{~d}^{-1}$ continued until the end of the model integration (i.e., September). The flux amount was underestimated in August and became comparable afterward with the trap values. The PON flux at $180 \mathrm{~m}$ corresponded to $79 \%$ of the ocean surface value exported from the sea ice bottom during JulySeptember 2011 (Fig. 9a, c). It should be noted that ice algae released from the skeletal layer were included immediately in the ice-derived PON without their biological activities in the present model setting. The major component of the PON flux originated from ice algae, as observed in the analysis of diatom valve compositions (Onodera et al., 2015). The PON flux derived from pelagic phytoplankton and zooplankton increased gradually in August and peaked at $6 \mu \mathrm{mol} \mathrm{N} \mathrm{m}{ }^{-2} \mathrm{~d}^{-1}$ in early September (Fig. 9c). In the 2011 case, the dominance of the ice-derived PON for the sinking flux was associated with a faster sinking speed (Sect. 2.2 and Fig. 3e), although the total biomass of pelagic plankton groups was 1 order of magnitude larger than that of the ice algal biomass (not shown). The sediment trap data captured another peak in PON flux during May 2011, when the model experiment could not reproduce the peak. The thick ice cover restricted spring bloom of ice algae and pelagic phytoplankton in the NAP region (Fig. 4b and Table 2). Instead, this event may have been caused by transport of shelf water with lithogenic materials of sea bottom sediment. A candidate driver was a cold-core eddy generated from a narrow jet along the Chukchi shelf break (Spall et al., 2008; Llinás et al., 2009). The background mechanisms for the spring peak are beyond the scope in the present study and will be analyzed in the future.

PON flux in the 2012 case produced a distinct midsummer peak at the ocean surface and at $180 \mathrm{~m}$, although the trapped sample volume was too low to estimate nitrogen content in summer 2012 (Fig. 9b, d). The trap depth of 247$319 \mathrm{~m}$ in 2012, which was deeper than that of $181-218 \mathrm{~m}$ in 2011, may have caused biases in the comparison between the 2 years. Importantly, PON flux in 2012 was markedly lower than the $1300 \mathrm{~m}$ flux in 2011 (Onodera et al., 2015). Again, most of the modeled PON flux was ice-derived. The contribution of pelagic-derived PON in the 2012 case was less than in the 2011 case. Enhanced sea ice melting of up to $4 \mathrm{~cm} \mathrm{~d}^{-1}$ assisted the peak flux in early August (Fig. 4c). The ice-ocean flux was remarkably greater than the ice algal production rate, indicating that one-dimensional sea ice processes cannot account for PON flux in the NAP region
(Fig. 9b). We trace lateral advection of the ice algal biomass around the Chukchi Borderland in the next section.

\subsection{Impact of great cyclone activity}

It was suggested that an extreme cyclone event was a supplementary factor for the drastic sea ice reduction, particularly in the western Arctic, and the subsequent record minimum extent of Arctic sea ice in summer 2012 (Simmonds and Rudeva, 2012; Zhang et al., 2013). A previous modeling analysis indicated that plankton productivity over the Chukchi, East Siberian, and Laptev shelves was enhanced by vertical mixing with nutrient replenishment and lateral plankton transport from the western Arctic basin during the cyclone storm (Zhang et al., 2014). It is assumed that synoptic cyclone activities have both positive and negative contributions to ice algal production. In the 2012 case, the eventlike shoaling of the upper part of the nutricline was caused by mixing and upwelling processes in the NAP region, where the southern part of the great cyclone passed and marginal ice floes were located in early August (Fig. 12a). The modeled vertical diffusivity was maintained at background values partly because strong density stratification suppressed turbulent mixing until July 2012 (Fig. 4f). During the cyclone event with high wind speeds (Table 2), vertical mixing of nearly $10 \mathrm{~cm}^{2} \mathrm{~s}^{-1}$ reached a depth of $20 \mathrm{~m}$ (Fig. 4f). Besides, the Ekman upwelling that continued from 15 July to 29 August could have worked on nutricline shoaling of $3.3 \mathrm{~m}$ (Fig. 4e). However, this timing of nutrient replenishment overlapped with the release of ice algae from the skeletal layer due to active sea ice melting (Fig. 8c), and the mixing and upwelling processes hardly enhanced ice algal productivity. Mechanical sea ice divergence associated with cyclonic wind fields rather contributed to the reduction in ice algal biomass in the specific region (Fig. 4d). Whereas the outward movement of sea ice floes itself did not lead to loss of ice algae, solar heat absorption into the exposed open water fractions enhanced lateral/bottom melting of sea ice and corresponding release of ice algae. The light conditions for ice algal growth also changed by during the cyclone event with extensive cloud cover. The NCEP/CFSR reanalysis data showed a depression in solar irradiance in the southern part of the cyclone passage, where an early August shortwave flux in 2012 was lower than that in 2011 by approximately $20 \mathrm{~W} \mathrm{~m}^{-2}$ (not shown). The negative anomaly of light intensity corresponded to a decrease in the light condition term for ice algal growth by less than 0.1 (Fig. 3b).

Here, we performed a sensitivity experiment in which all biogeochemical processes in the sea ice ecosystem were halted in August 2012. In this idealized experiment (called the "no ice algal activity case"), only lateral advection and sea ice-ocean fluxes were allowed in the sea ice column. All physical and pelagic marine ecosystem processes were calculated as in the original 2012 case. Although there was no ice algal production locally in August, both the modeled 
(a)

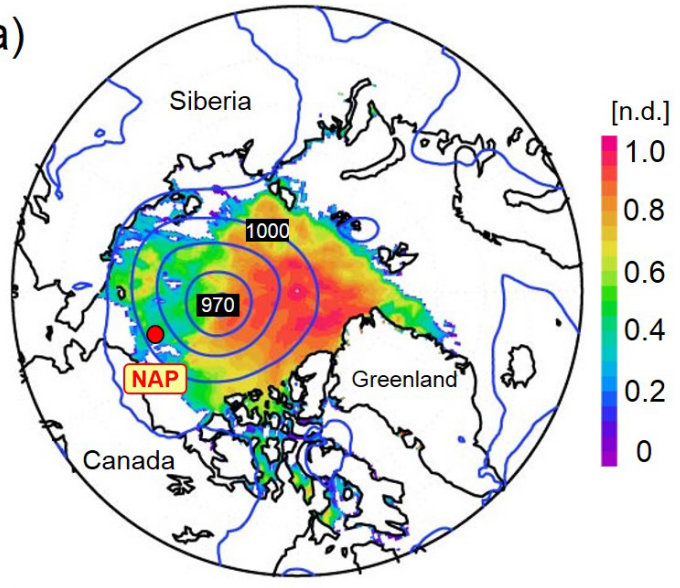

(c)

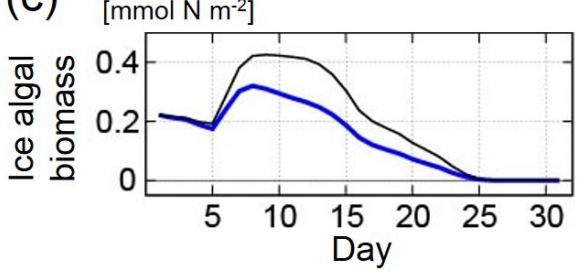

(b)

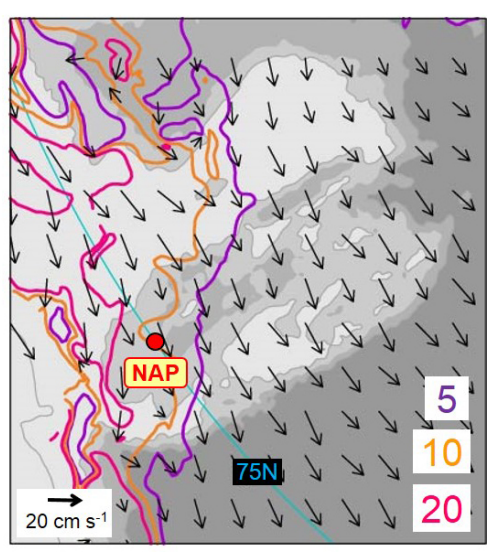

(d)

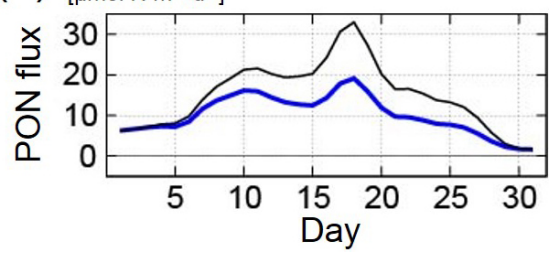

Figure 12. (a) NCEP/CFSR (contours) sea level pressure (hPa) and (shade) sea ice concentration (n.d.) on 6 August 2012. (b) Modeled (contours) PON flux at the depth of $180 \mathrm{~m}$ and (vectors) sea ice motion averaged for 3-10 August in the 2012 case. The flux contours of 5, 10, and $20 \mu \mathrm{mol} \mathrm{N} \mathrm{m} \mathrm{d}^{-1}$ are shown around the Chukchi Borderland. The sea ice motion is overlaid every 10 grid (i.e., approximately $50 \mathrm{~km}$ ), and its unit vector is $20 \mathrm{~cm} \mathrm{~s}^{-1}$. Red dots denote the location of Station NAP. August time series of the modeled (c) ice algal biomass $\left(\mathrm{mmol} \mathrm{N} \mathrm{m}{ }^{-2}\right.$ ) and (d) PON flux $\left(\mu \mathrm{mol} \mathrm{N} \mathrm{m}{ }^{-2} \mathrm{~d}^{-1}\right)$ in the 2012 case (black lines) and the no ice algal activity case (blue lines).

ice algal biomass and PON flux increased in the NAP region (Fig. 12c-d). These enhanced signals could only be explained by horizontal transport of larger biomass from neighboring regions. The differences from the original case corresponded to additional production of ice algae flowing into the NAP region. Thus, lateral advection was essentially important during the 2012 cyclone period.

In the 2012 case, westerly winds were intensified in the southern part of a cyclone passage and transported shelforigin ice algal patches toward the Northwind Ridge. Each sea ice floe moved approximately $150 \mathrm{~km}$ eastward during 3-10 August (Fig. 12b). Although the direction of sea ice motion $\left(87.4^{\circ} \mathrm{T}\right.$, where $0^{\circ} \mathrm{T}$ corresponds to true north) was similar to the satellite-based vectors $\left(82.8^{\circ} \mathrm{T}\right)$, the modeled drift speed $\left(20.3 \mathrm{~cm} \mathrm{~s}^{-1}\right)$ was markedly faster than the latter $\left(5.1 \mathrm{~cm} \mathrm{~s}^{-1}\right)$ during the cyclone period. It is plausible that the peculiar advection caused a sudden increase in ice algal biomass and an overestimation of the modeled PON flux in the NAP region (Figs. $6 \mathrm{a}$ and $12 \mathrm{~b}$ ). Local biases on sea ice velocity may have arisen from atmospheric momentum input and sea ice dynamics. In the present experiments, the conversion from SLP to the wind stress field (i.e., the AOMIP protocol referred to in Sect. 4.1) was formulated with specific turning angles, which varied depending on geostrophic wind speed (Proshutinsky and Johnson, 1997). Uncertainties in the reanalysis SLP data should also be considered, because the maximum strength of the great cyclone in $\mathrm{Au}$ gust 2012 calculated from the data assimilation system depended on the number of radiosonde profiles (Yamazaki et al., 2015). In addition, the traditional rheology of sea ice internal stress has been developed for climate models with grid spacing much coarser than $10 \mathrm{~km}$ and does not guarantee the accuracy of ice floe dynamics, especially in the marginal ice zone. Thus, speed and direction of the modeled ice algal advection around the Chukchi Borderland may have deviated in August 2012. These biases had less impact on the basin-scale sea ice and ocean circulation.

Another concern is the event-like deepening of the shallow sediment trap at Station NAP in July 2012 (Onodera et al., 2015). An intensified ocean current occasionally inclines the upper part of the bottom-tethered mooring system during storms. The anchored sea bottom depth of $1975 \mathrm{~m}$ and deepening of the trap from 260 to $320 \mathrm{~m}$ suggests an inclination angle of approximately $15^{\circ}$. It was reported that trapping efficiency and particle components were remarkably influenced by tilting $>30^{\circ}$ (Gardner, 1985). If this previous examination can be applied despite the different trap shape, a $15^{\circ}$ tilt should not significantly impact trapping efficiency. In addition, strong ocean currents $>10 \mathrm{~cm} \mathrm{~s}^{-1}$ sometimes reduce trapping efficiency (Baker et al., 1988). However, the modeled horizontal velocity at the trap depths was below $2 \mathrm{~cm} \mathrm{~s}^{-1}$, even during the cyclone period (not shown). 
It should also be noted that the trapped PON flux was continuously negligible throughout summer 2012, not only for the temporal cyclone event.

\section{Sensitivity experiments}

Although the present model experiments show the interannual variability in ice algal primary production and sinking biogenic particle flux in the NAP region, various sea icerelated processes still need to be considered. Here, we refer to the 2011 case analyzed in previous sections as the original case and performed sensitivity experiments using different model settings (Fig. 13 and Table 3). The first three cases (Cases 1-3) address uncertainties in the model parameters. In the next three cases (Cases 4-6), the grazing pressure on ice algae and the treatments of ice algae released into the water column are discussed. All the sensitivity experiments were initiated from the modeled fields at the beginning of March in the original case and conducted until September (i.e., 7month integration).

\subsection{Optimum light intensity for ice algal production (Case 1)}

It is difficult to estimate accurately the photosynthesisirradiance relationships of ice-related flora. Ice algae adapt well to weaker light intensity compared with that of pelagic phytoplankton (Arrigo et al., 2010). In the original case, the optimum light intensity for ice algal production $I_{\text {opti }}$ was set to $10 \mathrm{~W} \mathrm{~m}^{-2}$. Gradinger (2009) reported that the minimum requirement for ice algal growth was typically $<1 \mu \mathrm{E} \mathrm{m}^{-2} \mathrm{~s}^{-1}$ based on laboratory incubation experiments. When the relationship of $1 \mathrm{~W} \mathrm{~m}^{-2} \sim 4.56 \mu \mathrm{E} \mathrm{m}^{-2} \mathrm{~s}^{-1}$ is applied following Lavoie et al. (2005), $I_{\text {opti }}$ may be a smaller value. Here, we performed two sensitivity experiments with

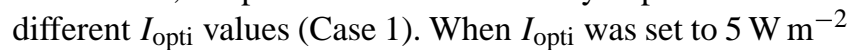
$\left(20 \mathrm{~W} \mathrm{~m}^{-2}\right)$, the summer peak in the light condition term was $0.9(0.3)$ in the NAP region (Figs. $3 b$ and 7a). Relaxing the light limitation resulted in an earlier and stronger ice algal bloom (Fig. 14a). The initial bloom occurred in early June and the second peak of ice algal biomass increased to $1.2 \mathrm{mmol} \mathrm{N} \mathrm{m}^{-2}$ (cf. $0.7 \mathrm{mmol} \mathrm{N} \mathrm{m}^{-2}$ in the original case). The phase and magnitude of the modeled PON flux shifted similarly and were still comparable with the trap data (Fig. 14b). In contrast, restricted light conditions dampened the ice algal productivity to a peak biomass of $0.1 \mathrm{mmol} \mathrm{N} \mathrm{m}^{-2}$ (Fig. 14a). The resultant decreased release of ice algae into the water column delayed the seasonal increase in the PON flux (Fig. 14b). The difference in ice algal biomass did not alter the flux during late summer, which was derived mainly from pelagic plankton. Based on these sensitivity experiments, an optimum light intensity of $10 \mathrm{~W} \mathrm{~m}^{-2}$ or below was recommended for the formulation adopted. Other choices can be made for the light condition term. Ice

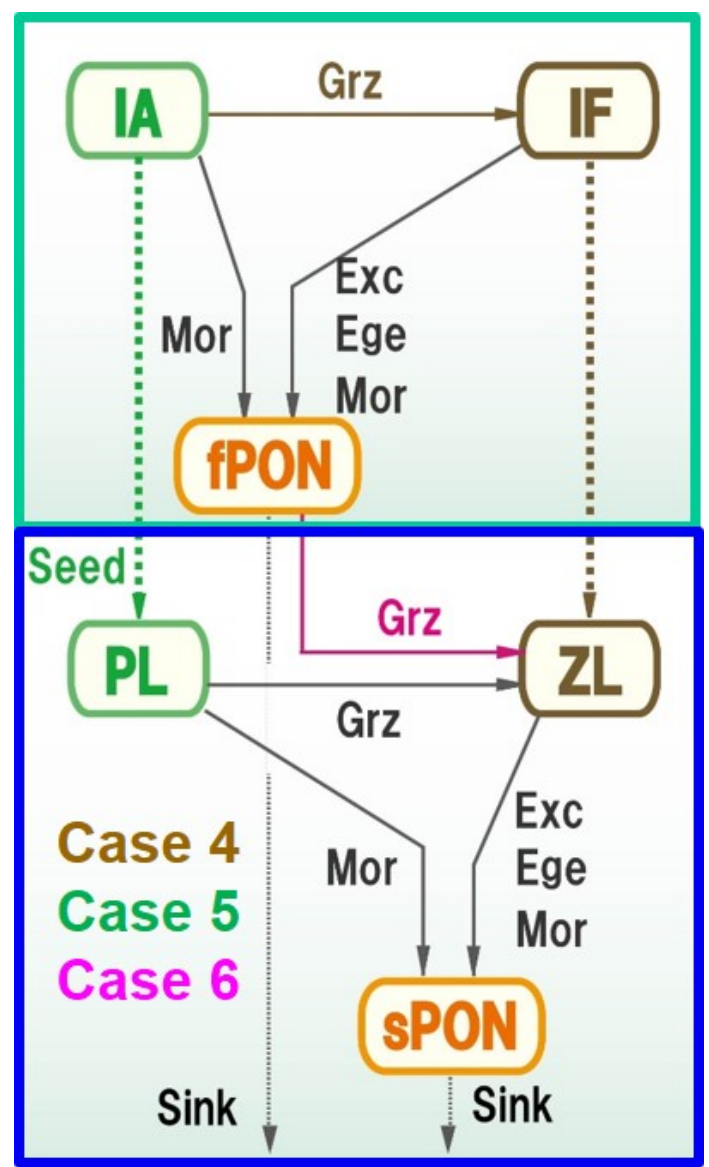

Figure 13. Schematic image of sensitivity experiments. In Case 4, the grazing pressure of ice-related fauna (IF) on ice algae (IA) and the transition from IF to mesozooplankton (ZL) after sea ice melting were calculated for the seeding. In Case 5, a part of IA was treated as large phytoplankton (PL) after sea ice melting. In Case 6, the ZL grazing on fast-sinking particulate organic nitrogen (fPON) was calculated in the water column, and the formulation of slow-sinking one (sPON) was not changed.

algae may not suffer from photo-inhibition even when the skeletal layer receives strong irradiance diffused from neighboring open leads during ice melting periods. A saturated light condition in accordance with increasing PAR can be represented, for example, by the hyperbolic tangent function used in Lavoie et al. (2005). Besides, the shelf-shading effect of ice algae reduces ice algal productivity in massive blooming regions (Pogson et al., 2011).

\subsection{Nutrient sources for ice algal production (Case 2)}

The present model adopted the hybrid nutrient uptake formulation. Ice algal productivity depends on the uptake ratio between sea ice and water nutrients. Here, we performed three experiments (Case 2). When the threshold value $\mathrm{KN}_{\text {upSKL }}$ is increased to $1.5 \mathrm{mmol} \mathrm{N} \mathrm{m}^{-2}$, (cf. $1.0 \mathrm{mmol} \mathrm{N} \mathrm{m}^{-2}$ in the original case), the ice algal growth rate reflects nutrient avail- 
Table 3. Parameters in the sensitivity experiments. Formulations are shown in Sects. 2.2 and 5.

\begin{tabular}{|c|c|c|c|c|}
\hline Parameter & Definition & Value & Unit & \\
\hline [Case 1-1] & $I_{\text {opti }}$ & Optimum light intensity & 5 & $\mathrm{~W} \mathrm{~m}^{-2}$ \\
\hline [Case 1-2] & $I_{\text {opti }}$ & Optimum light intensity & 20 & $\mathrm{~W} \mathrm{~m}^{-2}$ \\
\hline [Case 2-1] & $\mathrm{KN}_{\text {upSKL }}$ & Threshold value of ice/water nutrient uptake & 1.5 & $\mathrm{mmol} \mathrm{N} \mathrm{m}{ }^{-2}$ \\
\hline [Case 2-2] & $\mathrm{KN}_{\mathrm{upSKL}}$ & Threshold value of ice/water nutrient uptake & 0.5 & $\operatorname{mmol~} \mathrm{Nm}^{-2}$ \\
\hline [Case 2-3] & $\mathrm{RN}_{\text {upSKL }}$ & Ice nutrient uptake ratio & 0 & n.d \\
\hline [Case 3-1] & $V_{\text {fPONmin }}$ & Minimum sinking speed of ice-derived PON & 200 & $\mathrm{md}^{-1}$ \\
\hline [Case 3-2] & $V_{\mathrm{fPONmin}}$ & Minimum sinking speed of ice-derived PON & 20 & $\mathrm{md}^{-1}$ \\
\hline \multirow[t]{4}{*}{ [Case 4] } & $\mathrm{GrZ}_{\max }$ & Maximum rate of IF grazing on IA at $0^{\circ} \mathrm{C}$ & 0.4 & $\mathrm{~d}^{-1}$ \\
\hline & $\lambda$ & Ivlev constant & 1.4 & $\left.(\mathrm{mmolN} \mathrm{m})^{-3}\right)^{-1}$ \\
\hline & $\mathrm{IA}^{*}$ & Feeding threshold value & 0.04 & $\mathrm{mmol} \mathrm{N} \mathrm{m}^{-3}$ \\
\hline & $K_{\mathrm{Grz}}$ & Temperature coefficient for nitrification & 0.0693 & ${ }^{\circ} \mathrm{C}^{-1}$ \\
\hline & $R_{\mathrm{IA} 2 \mathrm{PL}}$ & Ratio of seeding from IA to PL & 0.5 & n.d. \\
\hline \multirow[t]{4}{*}{ [Case 6] } & $\mathrm{GrZ}_{\max }$ & Maximum rate of $\mathrm{ZL}$ grazing on ice-derived $\mathrm{PON}$ at $0^{\circ} \mathrm{C}$ & 0.4 & $d^{-1}$ \\
\hline & $\lambda$ & Ivlev constant & 1.4 & $\left.(\mathrm{mmolN} \mathrm{m})^{-3}\right)^{-1}$ \\
\hline & fPON* & Feeding threshold value & 0 & $\operatorname{mmol~} \mathrm{Nm}^{-3}$ \\
\hline & $K_{\mathrm{Grz}}$ & Temperature coefficient for nitrification & 0.0693 & ${ }^{\circ} \mathrm{C}^{-1}$ \\
\hline
\end{tabular}
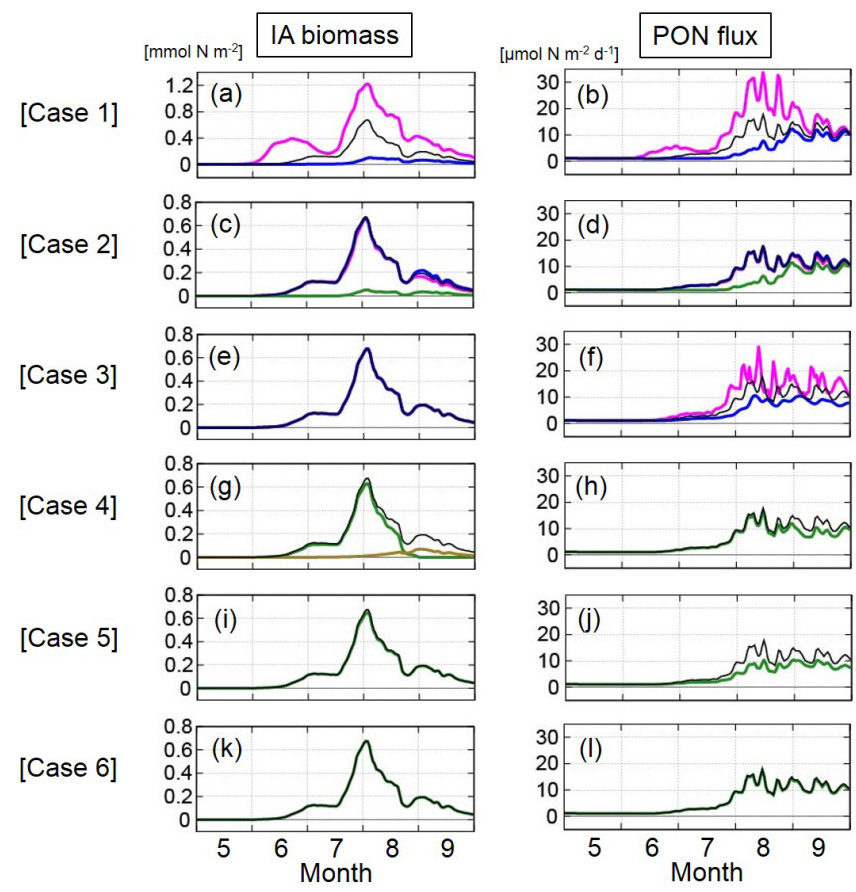

Figure 14. Modeled seasonal transition of $(\mathbf{a}, \mathbf{c}, \mathbf{e}, \mathbf{g}, \mathbf{i}, \mathbf{k})$ ice algal biomass (mmol $\mathrm{Nm}^{-2}$ ) and (b, d, f, h, j, l) PON flux $\left(\mu \mathrm{mol} \mathrm{N} \mathrm{m}{ }^{-2} \mathrm{~d}^{-1}\right)$ in the NAP region in (a-b) Case $1,(\mathbf{c}-\mathbf{d})$ Case 2, (e-f) Case 3, (g-h) Case 4, (i-j) Case 5, and (k-l) Case 6. Black thin lines correspond to the original 2011 case. The results with $I_{\text {opti }}$ of 5 (20) $\mathrm{W} \mathrm{m}^{-2}$ in Case $1, \mathrm{KN}_{\text {upSKL }}$ of 0.5 (1.5) $\mathrm{mmol} \mathrm{N} \mathrm{m}^{-2}$ in Case 2, PON sinking speed of $200(20) \mathrm{m} \mathrm{d}^{-1}$ in Case 3 are shown by magenta (blue) lines, respectively. The uptake formulation without sea ice nutrients results in a green line in Case 2. The biomass of ice-related fauna is shown by an olive line in Case 4 . ability in the sea ice column more strongly (Fig. 3c). Conversely, the decrease in $\mathrm{KN}_{\text {upSKL}}$ to $0.5 \mathrm{mmol} \mathrm{N} \mathrm{m}^{-2}$ accelerates the uptake of seawater nutrients. However, the modeled ice algal biomass and PON flux were not sensitive to this range of $\mathrm{KN}_{\mathrm{upSKL}}$ (Fig. 14c-d). As in the original case (Figs. 7c and 9a), the major source of ice algal production was seawater nutrients, even when only $20 \%$ of the biomass could utilize (i.e., $\mathrm{RN}_{\text {upSKL }}=0.8$ ). On the other hand, both the ice algal biomass and PON flux dropped remarkably in another experiment, in which uptake of sea ice nutrients was halted throughout the integration period (Fig. 14c-d). The slower growth rate with lower concentrations of seawater nutrients prevented ice algal seeds from blooming to the same level as in the original case before sea ice melting loss (Fig. 7d). The nutrient reservoir (and high concentration) in the sea ice column is important for the initial acceleration in an ice algal bloom, and nutrient availability in the ocean surface layer controls peak biomass.

The exchange rate of dissolved materials at the ice-water interface generally depends on molecular and turbulent diffusion processes. Lavoie et al. (2005) assumed that nutrient replenishment from the underlying mixed layer was proportional to friction velocity varying with the tidal cycle. The tidal effect is important in some regions such as the narrow straits of the Canadian Archipelago. However, exchange processes other than tidal mixing would also be necessary for the pan-Arctic Ocean modeling. In this connection, the ocean-to-ice nutrient flux is proportional to the $\mathrm{CF}_{\mathrm{OI}}$ coefficient during the ice freezing period. $\mathrm{A} \mathrm{CF}_{\mathrm{OI}}$ value of 0 or 1 is clearly unrealistic, because a significant portion of in situ seawater nutrients remains inside the sea ice column, and the residual is ejected to the underlying water column after sea ice freezing as well as salinity. The original case 
adopted a $\mathrm{CF}_{\mathrm{OI}}$ value of 0.3 , following a first-year ice salinity of $\sim 10 \mathrm{psu}$. Smaller $\mathrm{CF}_{\mathrm{OI}}$ values suppress nutrient accumulation in the skeletal layer during the freezing period and delay the initial ice algal bloom. Another assumption in the present model is that all of the sea ice nutrients are concentrated only in the skeletal layer with its constant thickness (cf. $2 \mathrm{~cm}$ in the original case), instead of brine pockets and channels that were not represented in the present model. An increase in the layer thickness reduces nutrient "concentration" (not total amount integrated in the entire sea ice column) and consequently delays an ice algal bloom. For example, a nitrate content of $0.6 \mathrm{mmol} \mathrm{N} \mathrm{m}^{-2}$, which was recorded in April of the original 2011 case (Fig. 8a), yields a concentration of $30 \mathrm{mmol} \mathrm{N} \mathrm{m}^{-3}\left(12 \mathrm{mmol} \mathrm{N} \mathrm{m}^{-3}\right)$ and a nitrate condition term of $0.91(0.80)$ in the skeletal layer with $2 \mathrm{~cm}(5 \mathrm{~cm})$ thickness. A time-varying biologically active layer with brine volumes (Tedesco et al., 2010) and multiple separate sea ice layers (Pogson et al., 2011) have been proposed to represent ice algal habitats more precisely. These uncertainties in sea ice nutrients seem to have an impact on ice algal production.

\subsection{Sinking speed of ice-derived PON (Case 3)}

The present model prescribed the fixed vertical profile of particle sinking speed (Fig. 3e). In the original case, the sinking speed of ice-derived PON varied from $50 \mathrm{~m} \mathrm{~d}^{-1}$ in the uppermost model layer to $200 \mathrm{~m} \mathrm{~d}^{-1}$ at a depth of $1000 \mathrm{~m}$. This speed range was comparable with the previous estimate of $>85 \mathrm{~m} \mathrm{~d}^{-1}$ between the shallow $(180 \mathrm{~m})$ and deep $(1300 \mathrm{~m})$ traps at Station NAP in August 2011 (Onodera et al., 2015). The PON exported from the sea ice bottom reached a depth of $180 \mathrm{~m}$ within 4 days under the model profile. As the decomposition rate from PON to ammonium and DON was set to $0.2 \mathrm{~d}^{-1}$ at $0^{\circ} \mathrm{C}$, approximately half $(47 \%)$ of the ice-derived PON was dissolved above a depth of $180 \mathrm{~m}$. Here, we performed two experiments (Case 3), in which the minimum sinking speed was set to $200(20) \mathrm{m} \mathrm{d}^{-1}$ in the faster (slower) sinking case (cf. $50 \mathrm{~m} \mathrm{~d}^{-1}$ in the original case). The remaining ratio of ice-derived $\mathrm{PON}$ after dissolution in these cases is theoretically 82 and $20 \%$ at a $180 \mathrm{~m}$ depth, respectively. Sinking speed hardly affected ice algal biomass (Fig. 14e) because the vertical nutrient profile in the water column had quite minor changes. On the other hand, PON flux differed significantly between the two cases (Fig. 14f). The earlier and larger peak in the PON flux appeared in the faster sinking case. The flux range obtained in Case 3 was smaller than the sensitivity to the optimum light intensity evaluated in Case 1.

Actual sedimentation of biogenic particles depends on the ballast distribution in addition to aggregation and elimination of light/fragile organic materials. When the source region of sea ice and surface water in the NAP region was the central Canada Basin, an insufficient quantity of ballast particles would have allowed slower PON sinking (Honjo et al., 2010). A variable sinking speed depending ballast particles may improve a model performance on the PON flux. Besides, the PON derived from phytoplankton and zooplankton possibly has a different sinking speed. The faster sinking speed of fecal pellets may account for a substantial portion of the particle flux as observed in Resolute Passage (Michel et al., 1996). Thus, many uncertainties remain with respect to the PON sinking process.

\subsection{Grazing on ice algae (Case 4)}

Previous observations detected a significant quantity of icerelated fauna including amphipods in the sea ice column (Bluhm et al., 2010). It was also reported that ice algal assemblages suspended under the ice bottom layer were an important food source for pelagic grazers (e.g., copepods) during the early stages of sea ice melting (Michel et al., 1996). Here, the impact of the grazing process on ice algal biomass was examined (Fig. 13). In Case 4, the concentration of icerelated fauna (IF) changed from zero in the original case (i.e., no grazing pressure on ice algae throughout the integration period) to $0.02 \mathrm{mmol} \mathrm{N} \mathrm{m}^{-3}$ on $1 \mathrm{March}$. The rate of IF grazing on ice algae was calculated following the Ivlev relationship:

$\operatorname{Grz}=\max \left\{0, \operatorname{Grz}_{\max } \times\left(1-\exp \left\{\lambda\left(\mathrm{IA}^{*}-\mathrm{IA}\right)\right\}\right)\right\}$,

where the maximum grazing rate $\mathrm{Grz}_{\max }$ of $0.4 \mathrm{~d}^{-1}$ at $0^{\circ} \mathrm{C}$, the Ivlev constant $\lambda$ of $1.4\left(\mathrm{mmol} \mathrm{N} \mathrm{m}^{-3}\right)^{-1}$, and the feeding threshold value $\mathrm{IA}^{*}$ of $0.04 \mathrm{mmol} \mathrm{N} \mathrm{m}^{-3}$ were given, as well as the grazing of mesozooplankton (ZL) on pelagic diatom (PL) in the original NEMURO model (Kishi et al., 2007). The Ivlev formulation assumes that no grazing occurs at an ice algal concentration IA lower than IA*. The modeled ice algal biomass showed the rapid decline after a similar peak compared with the original case (Fig. 4g). The ice-related fauna gradually increased following the ice algal bloom. A resultant peak of the IF biomass was $0.07 \mathrm{mmol} \mathrm{N} \mathrm{m}^{-2}$. This grazing process slightly contributed to the reduced PON flux (Fig. 14h). After sea ice melting, the released IF was included in ZL in the water column. For the sake of the enhanced grazing pressure in the water column, the phytoplankton biomass was also smaller than in the original case (not shown). We used same parameter values of IF grazing on IA as those of $\mathrm{ZL}$ on PL. When the skeletal layer is regarded as a refuge for ice algae from potential grazers, the maximum rate and consequent impact of grazing in the sea ice column should be smaller.

\subsection{Transfer from ice algae to phytoplankton (Case 5)}

It has been reported that a part of ice algae exported to the water column could continue their production activities as phytoplankton and become a zooplankton food source (Michel et al., 1993; Leventer, 2003; Gradinger et al., 2009). In Case 5, a constant ratio of ice algae released from the sea ice bottom was included in pelagic diatom (PL). The seeding partition was set to 0.5 , assuming that a half of the re- 
leased algae behaved in the form of living intact cells and the residual was included in the ice-related PON. Although the increased PL became a competitor of ice algae for the uptake of seawater nutrients in the uppermost ocean layer, the comparison with the original case showed little difference in the ice algal biomass (Fig. 14i). On the other hand, the icederived algae staying alive in the water column were eventually included in the slower-sinking PON produced from pelagic species. These processes contributed to the decrease in PON flux at the trap depth (Fig. 14j). There is a wide uncertainty of seeding ratios of the released ice algae. For example, the ratio was set to 0.1 by Jin et al. (2012). To assess an impact of ice algal seeding to phytoplankton bloom and sinking biogenic fluxes more accurately, simultaneous measurements of diatom compositions both in the sea ice and water columns would be necessary.

\subsection{Grazing on ice-derived PON (Case 6)}

Zooplankton grazing on sinking biogenic particles could influence the quantity and composition of export fluxes in the water column. In Case 6, ZL grazing on ice-derived PON (fPON in the present model) was considered using the Ivlev equation:

$\mathrm{Grz}=\max \left\{0, \mathrm{Grz}_{\max } \times\left(1-\exp \left\{\lambda\left(\mathrm{fPON}^{*}-\mathrm{fPON}\right)\right\}\right)\right\}$,

where $\mathrm{GrZ}_{\max }$ of $0.4 \mathrm{~d}^{-1}$ at $0^{\circ} \mathrm{C}$ and $\lambda$ of 1.4 (mmol $\left.\mathrm{N} \mathrm{m}^{-3}\right)^{-1}$ were given. The feeding threshold value fPON* was set to zero, and the contributions of other potential grazers (ZS and ZP in the present model) were neglected, for simplicity. This type of grazing hardly affected the ice algal biomass as in Case 3 (Fig. 14k), and the PON flux also showed little difference from the original case (Fig. 141). A fPON concentration of $0.5 \mu \mathrm{mol} \mathrm{N} \mathrm{m}^{-3}$ arising in midAugust yielded a grazing rate Grz of $2.8 \times 10^{-4} \mathrm{~d}^{-1}$. As the ZL concentration was still nearly $50 \mu \mathrm{mol} \mathrm{N} \mathrm{m}{ }^{-3}$ in the upper $50 \mathrm{~m}$, the grazed amount of fPON was $0.014 \mu \mathrm{mol} \mathrm{N} \mathrm{m}{ }^{-3} \mathrm{~d}^{-1}$ at the flux peak. The grazed ratio of $0.028 \mathrm{~d}^{-1}$ based on the above estimate was 1 order of magnitude smaller than the decomposition rate (see Sect. 5.3). This result indicated that the impact of zooplankton grazing on ice-derived PON was negligible, at least in the NAP region. In addition, zooplankton would not efficiently capture fast-sinking aggregates as shown in Lake Saroma (Nishi and Tabeta, 2005). Suspended algae are rather preferable for zooplankton growth (Michel et al., 1996).

\section{Summary}

Biogeochemical structures in the western Arctic were addressed using a sea ice-ocean modeling approach. In the present work, a sea ice ecosystem with ice algal activity was newly incorporated into a pelagic marine ecosystem model. We assumed that ice algae could utilize nutrients (nitrate, ammonium, and silicate) both in the skeletal layer of sea ice and in the ocean surface layer (i.e., seawater nutrients). The ratio of the nutrient source varied depending on ice algal biomass. This "hybrid-type" nutrient uptake formulation is an option to represent more realistic characteristics of ice algal biology.

The modeled ice algal primary production demonstrated noticeable interannual variability as suggested by previous sediment trap analyses in the NAP region. It was found that year-to-year changes in ice algal production were closely related to pan-Arctic wind patterns. In winter 2010-2011, strong easterly winds around the Beaufort High induced basin-ward Ekman transport of shelf-origin surface water and vertical turbulent mixing with underlying nutricline waters. The higher nitrate concentrations were then distributed in the southern Beaufort Sea and the Chukchi Borderland. On the other hand, in winter 2011-2012, northwesterly winds associated with an extension of the Siberian High distributed oligotrophic water from the central Canada Basin toward the northern Chukchi shelf. Hence, ice algal productivity in the NAP region was suppressed by a deeper nutricline, in addition to cloud shading of solar irradiance, until early summer.

The modeled summer biogenic particle flux in the NAP region was comparable with the sediment trap data in 2011 and but was remarkably overestimated in 2012. In summer 2012, lateral advection processes resulted in the enhanced PON flux, because the ice-ocean flux exceeded ice algal production in the same location. In August, westerly winds were intensified in the southern part of the cyclone and transported the shelf-origin ice algal patches toward the NAP region. This cyclone event may have caused the model biases on sea ice motion and biogenic particle flux. We further addressed several model uncertainties with sensitivity experiments. The modeled ice algal biomass was highly sensitive to optimum light intensity. PON flux in the water column varied depending on particle sinking speed in addition to ice algal productivity. The impacts of various grazing processes on PON flux were relatively minor within the present cases. However, there still remain more unknown issues on ice algae. For example, resting spores should be considered for wintering strategy. Successive observations and model improvements are indispensable to gather ubiquitous findings on ice-related biological processes.

Acknowledgements. This study is supported by the Grant-in-Aid for Scientific Research of Japan Society for the Promotion of Science (JSPS) (KAKENHI 22221003, 26800248, and 15H01736) and the GRENE Arctic Climate Change Research Project. Modeling experiments were executed using the Earth Simulator of Japan Agency for Marine-Earth Science and Technology (JAMSTEC). The article was much improved by Dr. Nadja Steiner and an anonymous referee.

Edited by: T. Hirawake 


\section{References}

Aota, M. and Ishikawa, M.: On the extinction coefficient of sea ice, Low Temperature Science Series A, 40, 127-135, 1982.

Arrigo, K. R., Kremer, J. N., and Sullivan, C. W.: A simulated Antarctic fast ice ecosystem, J. Geophys. Res., 98, 6929-6946, 1993.

Arrigo, K. R., Mock, T., and Lizotte, M. P.: Primary producers and sea ice, in: Sea Ice, edited by: Thomas, D. N. and Dieckmann, G. S., Wiley-Blackwell, Oxford, 283-325, 2010.

Baker, E. T., Milburn, H. B., and Tennant, D. A.: Field assessment of sediment trap efficiency under varying flow conditions, J. Mar. Res., 46, 573-592, 1998.

Bitz, C. M., Holland, M. M., Weaver, A. J., and Eby, M.: Simulating the ice-thickness distribution in a coupled climate model, J. Geophys. Res., 106, 2441-2463, 2001.

Bitz, C. M. and Lipscomb, W. H.: An energy-conserving thermodynamic model of sea ice, J. Geophys. Res., 104, 15669-15677, 1999.

Bluhm, B. A., Gradinger, R. R., and Schnack-Schiel, S. B.: Sea ice meio- and macro-fauna, in: Sea Ice, edited by: Thomas, D. N. and Dieckmann, G. S., Wiley-Blackwell, Oxford, 357-393, 2010.

Boetius, A., Albrecht, S, Bakker, K., Bienhold, C., Felden, J., Fernández-Méndez, M., Hendricks, S., Katlein, C., Lalande, C., Krumpen, T., Nicolaus, M., Peeken, I., Rabe, B., Rogacheva, A., Rybakova, E., Somavilla, R., Wenzhöfer, F., and RV Polarstern ARK27-3-Shipboard Science Party: Export of algal biomass from the melting Arctic sea ice, Science, 339, 1430-1432, 2013.

Cota, G. F. and Smith, R. E. H.: Ecology of bottom ice algae: II. Dynamics, distributions and productivity, J. Marine Syst., 2, 279 295, 1991

Cota, G. F., Legendre, L., Gosselin, M., and Ingram, R. G.: Ecology of bottom ice algae: I. Environmental controls and variability, J. Marine Syst., 2, 257-277, 1991.

Cremer, H: Distribution patterns of diatom surface sediment assemblages in the Laptev Sea (Arctic Ocean), Mar. Micropaleontol., 38, 39-67, 1999.

Deal, C., Jin, M., Elliott, S., Hunke, E., Maltrud, M., and Jeffery, N.: Large-scale modeling of primary production and ice algal biomass within arctic sea ice in 1992, J. Geophys. Res., 116, C07004, doi:10.1029/2010JC006409, 2011.

Dupont, F.: Impact of sea-ice biology on overall primary production in a biophysical model of the pan-Arctic Ocean, J. Geophys. Res., 117, C00D17, doi:10.1029/2011JC006983, 2012.

Fahl, K. and Nöthig, E.-M.: Lithogenic and biogenic particle fluxes on the Lomonosov Ridge (central Arctic Ocean) and their relevance for sediment accumulation: Vertical vs. lateral transport, Deep-Sea Res. Pt. I, 54, 1256-1272, 2007.

Forest, A., Sampei, M., Hattori, H., Makabe, R., Sasaki, H., Fukuchi, M., Wassmann, P., and Fortier, L.: Particulate organic carbon fluxes on the slope of the Mackenzie Shelf (Beaufort Sea): Physical and biological forcing of shelf-basin exchanges, J. Marine Syst., 68, 39-54, 2007

Garcia, H. E., Locarnini, R. A., Boyer, T. P., Antonov, J. I., Baranova, O. K., Zweng, M. M., Reagan, J. R., and Johnson, D. R.: World Ocean Atlas 2013, Volume 4: Dissolved Inorganic Nutrients (phosphate, nitrate, silicate), edited by: Levitus, S., Ed., Mishonov, A., Technical Ed., NOAA Atlas NESDIS, 76, 25 pp., 2013.
Gardner, W. D.: The effect of tilt on sediment trap efficiency, DeepSea Res., 32, 349-361, 1985.

Gosselin, M., Levasseur, M., Wheeler, P. A., Horner, R. A., and Booth, B. C.: New measurements of phytoplankton and ice algal production in the Arctic Ocean, Deep-Sea Res. Pt. II, 44, 1623 1644, 1997.

Gradinger, R.: Sea-ice algae: Major contributors to primary production and algal biomass in the Chukchi and Beaufort Seas during May/June 2002, Deep-Sea Res. Pt. II, 56, 1201-1212, 2009.

Haas, C., Hendricks, S., Eicken, H., and Herber, A.: Synoptic airborne thickness surveys reveal state of Arctic sea ice cover, Geophys. Res. Lett., 37, L09501, doi:10.1029/2010GL042652, 2010.

Hasumi, H.: CCSR Ocean Component Model (COCO) version 4.0, Center for Climate System Research Report, University of Tokyo, Tokyo, 25, 103 pp., 2006.

Honda, M. C., Kawakami, H., Watanabe, S., and Saino, T.: Concentration and vertical flux of Fukushima-derived radiocesium in sinking particles from two sites in the Northwestern Pacific Ocean, Biogeosciences, 10, 3525-3534, doi:10.5194/bg-103525-2013, 2013

Honjo, S., Krishfield, R. A., Eglinton, T. I., Manganini, S. J., Kemp, J. N., Doherty, K., Hwang, J., McKee, T. K., and Takizawa, T.: Biological pump processes in the cryopelagic and hemipelagic Arctic Ocean: Canada Basin and Chukchi Rise, Prog. Oceanogr., 85, 137-170, 2010.

Hunke, E. C. and Dukowicz, J. K.: An elastic-viscous-plastic model for sea ice dynamics, J. Phys. Oceanogr., 27, 1849-1867, 1997.

Hwang, J., Kim, M., Manganini, S. J., McIntyre, C. P., Haghipour, N., Park, J. J., Krishfield, R. A., Macdonald, R. W., McLaughlin, F. A., and Eglinton, T. I.: Temporal and spatial variability of particle transport in the deep Arctic Canada Basin, J. Geophys. Res., 120, 2784-2799, doi:10.1002/2014JC010643, 2015.

Ikenoue, T., Bjørklund, K. R., Kruglikova, S. B., Onodera, J., Kimoto, K., and Harada, N.: Flux variations and vertical distributions of siliceous Rhizaria (Radiolaria and Phaeodaria) in the western Arctic Ocean: indices of environmental changes, Biogeosciences, 12, 2019-2046, doi:10.5194/bg-12-2019-2015, 2015.

Jin, M., Deal, C. J., Wang, J., Shin, K.-H., Tanaka, N., Whitledge, T. E., Lee, S. H., and Gradinger, R. R.: Controls of the landfast ice-ocean ecosystem offshore Barrow, Alaska, Ann. Glaciol., 44, 63-72, 2006

Jin, M., Deal, C., Lee, S. H., Elliott, S., Hunke, E., Maltrud, and M., Jeffery, N.: Investigation of Arctic sea ice and ocean primary production for the period 1992-2007 using a 3-D global ice-ocean ecosystem model, Deep-Sea Res. Pt. II, 81-84, 28-35, doi:10.1016/j.dsr2.2011.06.003, 2012.

Kishi, M. J., Kashiwai, M., Ware, D. M., Megrey, B. A., Eslinger, D. L., Werner, F. E., Noguchi-Aita, M., Azumaya, T., Fujii, M., Hashimoto, S., Huang, D., Iizumi, H., Ishida, Y., Kang, S., Kantakov, G. A., Kim, H., Komatsu, K., Navrotsky, V. V., Smith, S. L., Tadokoro, K., Tsuda, A., Yamamura, O., Yamanaka, Y., Yokouchi, K., Yoshie, N., Zhang, J., Zuenko, Y. I., and Zvalinsky, V. I.: NEMURO-a lower trophic level model for the North Pacific marine ecosystem, Ecol. Model., 202, 12-25, 2007.

Lalande, C., Nöthig, E.-M., Somavilla, R., Bauerfeind, E. Shevchenko, V., and Okolodkov, Y.: Variability in under-ice export fluxes of biogenic matter in the Arctic Ocean, Global Biogeochem. Cy., 28, 571-583, doi:10.1002/2013GB004735, 2014 
Lavoie, D., Denman, K., and Michel, C.: Modeling ice algal growth and decline in a seasonally ice-covered region of the Arctic (Resolute Passage, Canadian Archipelago), J. Geophys. Res., 110, C11009, doi:10.1029/2005JC002922, 2005.

Lavoie, D., Denman, K. L., and Macdonald, R. W.: Effects of future climate change on primary productivity and export fluxes in the Beaufort Sea, J. Geophys. Res., 115, C04018, doi:10.1029/2009JC005493, 2010.

Leonard, B. P., MacVean, M. K., and Lock, A. P.: The flux-integral method for multi-dimensional convection and diffusion, NASA Tech. Memo, 106679/ICOMP-94-13, NASA, Washington, D. C., 1994.

Leventer, A.: Particulate flux from sea ice in polar waters, in: Sea Ice, edited by: Thomas, D. N. and Dieckmann, G. S., WileyBlackwell, Oxford, 303-332, 2003.

Llinás, L., Pickart, R. S., Mathis, J. T., and Smith, S. L.: Zooplankton inside an Arctic Ocean cold-core eddy: Probable origin and fate, Deep-Sea Res. Pt. II, 56, 1290-1304, 2009.

Lipscomb, W. H.: Remapping the thickness distribution in sea ice models, J. Geophys. Res., 106, 13989-14000, 2001.

Matsuno, K., Yamaguchi, A., Fujiwara, A., Onodera, J., Watanabe, E., Harada, N., and Kikuchi, T.: Seasonal changes in the population structure of dominant planktonic copepods collected using a sediment trap moored in the western Arctic Ocean, J. Nat. Hist., doi:10.1080/00222933.2015.1022613, 2015.

McLaughlin, F. A. and Carmack, E. C.: Deepening of the nutricline and chlorophyll maximum in the Canada Basin interior, 2003-2009, Geophys. Res. Lett., 37, L24602, doi:10.1029/2010GL045459, 2010.

Michel, C., Legendre, L., Therriault, J.-C., Demers, S., and Vandevelde T.: Springtime coupling between ice algal and phytoplankton assemblages in southeastern Hudson Bay, Canadian Arctic, Polar Biol., 13, 441-449, 1993.

Michel, C., Legendre, L., Ingram, R. G., Gosselin, M., and Levasseur, M.: Carbon budget of sea-ice algae in spring: Evidence of a significant transfer to zooplankton grazers, J. Geophys. Res., 101, 18345-18360, 1996.

Nishi, Y. and Tabeta, S.: Analysis of the contribution of ice algae to the ice-covered ecosystem in Lake Saroma by means of a coupled ice-ocean ecosystem model, J. Marine Syst., 55, 249-270, 2005.

Nishino, S., Kikuchi, T., Yamamoto-Kawai, M., Kawaguchi, Y., Hirawake, T., and Itoh, M.: Enhancement/reduction of biological pump depends on ocean circulation in the sea-ice reduction regions of the Arctic Ocean, J. Oceanogr., 67, 305-314, doi:10.1007/s10872-011-0030-7, 2011.

Noh, Y. and Kim, H. J.: Simulations of temperature and turbulence structure of the oceanic boundary layer with the improved nearsurface process, J. Geophys. Res., 104, 15621-15634, 1999.

Onodera, J., Watanabe, E., Harada, N., and Honda, M. C.: Diatom flux reflects water-mass conditions on the southern Northwind Abyssal Plain, Arctic Ocean, Biogeosciences, 12, 1373-1385, doi:10.5194/bg-12-1373-2015, 2015.

Peralta-Ferriz, C. and Woodgate, R. A.: Seasonal and interannual variability of pan-Arctic surface mixed layer properties from 1979 to 2012 from hydrographic data, and the dominance of stratification for multiyear mixed layer depth shoaling, Prog. Oceanogr., 134, 19-53, doi:10.1016/j.pocean.2014.12.005, 2015.
Pogson, L., Tremblay, B., Lavoie, D., Michel, C., and Vancoppenolle, M.: Development and validation of a one-dimensional snow-ice algae model against observations in Resolute Passage, Canadian Arctic Archipelago, J. Geophys. Res., 116, C040110, doi:10.1029/2010JC006119, 2011.

Proshutinsky, A., Krishfield, R., Timmermans, M.-L., Toole, J., Carmack, E., McLaughlin, F., Williams, W. J., Zimmermann, S., Itoh, M., and Shimada, K.: Beaufort Gyre freshwater reservoir: State and variability from observations, J. Geophys. Res., 114, C00A10, doi:10.1029/2008JC005104, 2009.

Proshutinsky, A. Y. and Johnson, M. A.: Two circulation regimes of the wind-driven Arctic Ocean, J. Geophys. Res., 102, 1249312514, 1997.

Saha, S., Moorthi, S., Pan, H.-L., Wu, X., Wang, J., Nadiga, S., Tripp, P., Kistler, R., Woollen, J., Behringer, D., Liu, H., Stokes, D., Grumbine, R., Gayno, G., Wang, J., Hou, Y.-T., Chuang, H.Y., Juang, H.-M. H., Sela, J., Iredell, M., Treadon, R., Kleist, D., Delst, P. V., Keyser, D., Derber, J., Ek, M., Meng, J., Wei, H., Yang, R., Lord, S., Dool, H. V. D., Kumar, A., Wang, W., Long, C., Chelliah, M., Xue, Y., Huang, B., Schemm, J.-K., Ebisuzaki, W., Lin, R., Xie, P., Chen, M., Zhou, S., Higgins, W., Zou, C.-Z., Liu, Q., Chen, Y., Han, Y., Cucurull, L., Reynolds, R. W., Rutledge, G., and Goldberg, M: The NCEP Climate Forecast System reanalysis, B. Am. Meteorol. Soc., 91, 1015-1057, doi:10.1175/2010BAMS3001.1, 2010.

Simmonds, I. and Rudeva, I.: The great Arctic cyclone of August 2012, Geophys. Res. Lett., 39, L23709, doi:10.1029/2012GL054259, 2012.

Spall, M. A., Pickart, R. S., Frantantoni, P. S., and Plueddemann, A. J.: Western Arctic shelfbreak eddies: Formation and transport, J. Phys. Oceanogr., 38, 1644-1668, 2008.

Tedesco, L., Vichi, M., Haapala, J., and Stipa, T.: A dynamic Biologically Active Layer for numerical studies of the sea ice ecosystem, Ocean Model., 35, 89-104, 2010.

Vancoppenolle, M., Goosse, H., de Montety A., Fichefet, T., Tremblay, B., and Tison, J.-L.: Modeling brine and nutrient dynamics in Antarctic sea ice: The case of dissolved silica, J. Geophys. Res., 115, C02005, doi:10.1029/2009JC005359, 2010.

Wassmann, P.: Arctic marine ecosystems in an era of rapid climate change, Prog. Oceanogr., 90, 1-17, 2011.

Watanabe, E.: Beaufort shelf break eddies and shelf-basin exchange of Pacific summer water in the western Arctic Ocean detected by satellite and modeling analyses, J. Geophys. Res., 116, C08034, doi:10.1029/2010JC006259, 2011.

Watanabe, E., Kishi, M. J., Ishida, A., and Aita, M. N.: Western Arctic primary productivity regulated by shelf-break warm eddies, J. Oceanogr., 68, 703-718, doi:10.1007/s10872-012-0128-6, 2012.

Watanabe, E., Onodera, J., Harada, N., Honda, M. C., Kimoto, K., Kikuchi, T., Nishino, S., Matsuno, K., Yamaguchi, A., Ishida, A., and Kishi, M. J.: Enhanced role of eddies in the Arctic marine biological pump, Nature Communications, 5, 3950, doi:10.1038/ncomms4950, 2014.

Woodgate, R. A., Aagaard, K., and Weingartner, T. J.: Monthly temperature, salinity, and transport variability of the Bering Strait through flow, Geophys. Res. Lett., 32, L04601, doi:10.1029/2004GL021880, 2005.

Yamazaki, A., Inoue, J., Dethloff, K., Maturilli, M., and KönigLanglo, G.: Impact of radiosonde observations on forecasting 
summertime Arctic cyclone formation, J. Geophys. Res., 120, 3249-3273, doi:10.1002/2014JD022925, 2015.

Yang, J.: Seasonal and interannual variability of downwelling in the Beaufort Sea, J. Geophys. Res., 114, C00A14, doi:10.1029/2008JC005084, 2009.

Zhang, J., Spitz, Y. H., Steele, M., Ashjian, C., Campbell, R., Berline, L., and Matrai, P.: Modeling the impact of declining sea ice on the Arctic marine planktonic ecosystem, J. Geophys. Res., 115, C10015, doi:10.1029/2009JC005387, 2010.

Zhang, J., Lindsay, R., Schweiger, A., and Steele, M.: The impact of an intense summer cyclone on 2012 Arctic sea ice retreat, Geophys. Res. Lett., 40, 720-726, doi:10.1002/grl.50190, 2013.
Zhang, J., Ashjian, C., Campbell, R., Hill, V., Spitz, Y. H., and Steele, M.: The great 2012 Arctic Ocean summer cyclone enhanced biological productivity on the shelves, J. Geophys. Res., 119, 297-312, doi:10.1002/2013JC009301, 2014.

Zhao, M., Timmermans, M.-L., Cole, S., Krishfield, R., Proshutinsky, A., and Toole, J.: Characterizing the eddy field in the Arctic Ocean halocline, J. Geophys. Res., 119, 8800-8817, doi:10.1002/2014JC010488, 2014. 